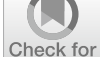

updates

Cite as

Nano-Micro Lett.

(2022) $14: 40$

Received: 25 August 2021

Accepted: 7 November 2021

Published online: 23 December 2021

(C) The Author(s) 2021

\section{High-Index Faceted Nanocrystals as Highly Efficient Bifunctional Electrocatalysts for High-Performance Lithium-Sulfur Batteries}

\author{
Bo Jiang ${ }^{1}$, Da Tian ${ }^{1}$, Yue Qiu ${ }^{1}$, Xueqin Song ${ }^{1}$, Yu Zhang ${ }^{3}$, Xun Sun ${ }^{1}$, Huihuang Huang ${ }^{1}$, \\ Chenghao Zhao ${ }^{1}$, Zhikun Guo ${ }^{1}$, Lishuang Fan $^{1,2} \bowtie$, Naiqing Zhang ${ }^{1,2} \bowtie$
}

\title{
HIGHLIGHTS
}

- High-index faceted $\mathrm{Fe}_{2} \mathrm{O}_{3}$ nanocrystals with abundant unsaturated $\mathrm{Fe}$ sites not only have strong adsorption capacity to anchor LiPSs but also have superior catalytic activity to facilitate the redox conversion of LiPSs and reduce the decomposition energy barrier of $\mathrm{Li}_{2} \mathrm{~S}$.

- Our work deepens the comprehending of facet-dependent activity of catalysts in Li-S chemistry and affords a novel perspective for the design of advanced sulfur electrodes.

\begin{abstract}
Precisely regulating of the surface structure of crystalline materials to improve their catalytic activity for lithium polysulfides is urgently needed for high-performance lithium-sulfur ( $\mathrm{Li}-\mathrm{S}$ ) batteries. Herein, high-index faceted iron oxide $\left(\mathrm{Fe}_{2} \mathrm{O}_{3}\right)$ nanocrystals anchored on reduced graphene oxide are developed as highly efficient bifunctional electrocatalysts, effectively improving the electrochemical performance of $\mathrm{Li}-\mathrm{S}$ batteries. The theoretical and experimental results all indicate that high-index $\mathrm{Fe}_{2} \mathrm{O}_{3}$ crystal facets with abundant unsaturated coordinated Fe sites not only have strong adsorption capacity to anchor polysulfides but also have high catalytic activity to facilitate the redox transformation of polysulfides and reduce the decomposition energy barrier of $\mathrm{Li}_{2} \mathrm{~S}$. The $\mathrm{Li}-\mathrm{S}$ batteries with these bifunctional electrocatalysts exhibit high initial capacity of $1521 \mathrm{mAh} \mathrm{g}^{-1}$ at 0.1

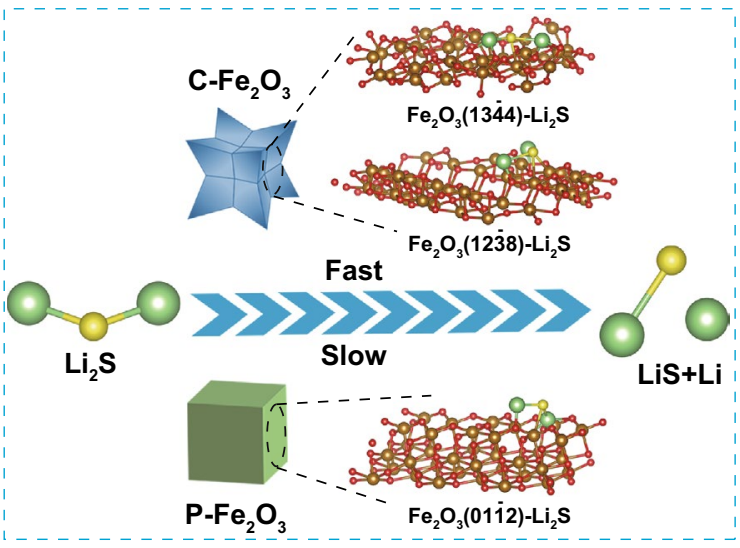
$\mathrm{C}$ and excellent cycling performance with a low capacity fading of $0.025 \%$ per cycle during 1600 cycles at 2 C. Even with a high sulfur loading of $9.41 \mathrm{mg} \mathrm{cm}^{-2}$, a remarkable areal capacity of $7.61 \mathrm{mAh} \mathrm{cm}^{-2}$ was maintained after 85 cycles. This work provides a new strategy to improve the catalytic activity of nanocrystals through the crystal facet engineering, deepening the comprehending of facet-dependent activity of catalysts in Li-S chemistry, affording a novel perspective for the design of advanced sulfur electrodes.
\end{abstract}

KEYWORDS High-index faceted; $\mathrm{Fe}_{2} \mathrm{O}_{3}$ nanocrystals; Unsaturated coordinated; Lithium-sulfur batteries; Electrocatalysis

Bo Jiang, Da Tian and Yue Qiu contributed equally to this work.

$\bowtie$ Lishuang Fan, fanlsh@hit.edu.cn; Naiqing Zhang, znqmww@163.com

1 State Key Laboratory of Urban Water Resource and Environment, School of Chemistry and Chemical Engineering, Harbin Institute of Technology, Harbin 150001, People's Republic of China

2 Academy of Fundamental and Interdisciplinary Sciences, Harbin Institute of Technology, Harbin 150001, People's Republic of China

3 School of Energy Science and Engineering, Harbin Institute of Technology, Harbin 150001, People's Republic of China 


\section{Introduction}

The booming progress of luggable electronic devices and electric vehicles urgently needs electrochemical energy storage equipment with higher power density and lower cost than lithium-ion batteries (LIBs) [1-4]. Lithium-sulfur ( $\mathrm{Li}-\mathrm{S})$ batteries with high theoretical capacity $\left(1672 \mathrm{mAh} \mathrm{g}^{-1}\right)$, remarkable energy density (2600 Wh $\mathrm{kg}^{-1}$ ) and low cost, as one of the most promising substitutes to the current LIBs, have attracted widespread attention and ever-increasing research enthusiasm [1, 5-8]. However, the commercial application of $\mathrm{Li}-\mathrm{S}$ batteries is still constrained by many challenges. The inevitable dissolution of lithium polysulfides (LiPSs) intermediates in the electrolytes and the shuttling of LiPSs between the cathode and anode result in low sulfur utilization, swift capacity degradation and the corrosion of lithium anode [9-16]. In addition, the sluggish redox kinetics resulting from insulating sulfur and $\mathrm{Li}_{2} \mathrm{~S}$ during discharge/charge cycles limits the efficient conversion of sulfur species, impairing the rate performance and cycling stability of $\mathrm{Li}-\mathrm{S}$ batteries [17-22]. Consequently, various materials have been developed and applied to Li-S batteries to tackle aforementioned issues, such as carbon matrix materials [23, 24], metal oxides [3, 25-27], metal nitrides [28, 29] and metal sulfides [30-32].

Although constructing these host materials improves the electrochemical performance of $\mathrm{Li}-\mathrm{S}$ batteries to a certain extent, most of the existing researches mainly dedicated on the screening of catalytic materials which can anchor and reversibly transform LiPSs, as well as optimizing electrode materials by designing the composition, microstructure and electronic structure of the bulk phase. It is well known that both the adsorption of LiPSs and the catalytic conversion of sulfur species occur on the surfaces of electrode material $[33,34]$. The surface structure of the electrode materials will directly affect the adsorption and catalytic conversion of sulfur species. However, this significant crystal facet effect in the sulfur electrochemistry has been neglected and the corresponding researches have not been reported so far. The different crystal facets exposed on electrode materials have disparate atomic arrangement [35-38], especially the high-index crystallographic planes with high densities of periodic atom steps, ledges and unsaturated coordinated sites [39-43], which may effectively regulate the adsorption and catalytic transformation of sulfur species.

Herein, the crystal facet effect in Li-S electrochemistry was systematically investigated by the design and synthesis of the high-index facet nanocrystals based on a series of electrochemical experiments and density functional theory (DFT) calculations. This work exhibited profound insight into the structure-activity relationship between the surface structures of crystal materials and the redox kinetics for sulfur species, which provided more direct theoretical basis for the rational design of advanced $\mathrm{Li}-\mathrm{S}$ electrode materials in the future. In view of the low cost and nontoxicity [44-46], $\mathrm{Fe}_{2} \mathrm{O}_{3}$ nanocrystals with different facets were fabricated on the reduced graphene oxide $\left(\mathrm{Fe}_{2} \mathrm{O}_{3}-\mathrm{G}\right)$ for investigating the crystal facet effect. The theoretical and experimental results demonstrated that concave $\mathrm{Fe}_{2} \mathrm{O}_{3}$ nanocubes $\left(\mathrm{C}-\mathrm{Fe}_{2} \mathrm{O}_{3}\right)$ bounded by highindex $\{12 \overline{3} 8\}$ and $\{13 \overline{4} 4\}$ facets not only manifested superior inhibition effect on the shuttle of polysulfides but also had more robust catalytic activity for the transformation of sulfur species than $\mathrm{Fe}_{2} \mathrm{O}_{3}$ pseudocubes $\left(\mathrm{P}-\mathrm{Fe}_{2} \mathrm{O}_{3}\right)$ enclosed by $\{01 \overline{1} 2\}$ facets. The abundant unsaturated coordinated $\mathrm{Fe}$ sites on the high-index faceted $\mathrm{C}-\mathrm{Fe}_{2} \mathrm{O}_{3}$ as the active centers boosted the chemical adsorption for LiPSs, accelerated polysulfides conversion, in particular, enhanced the decomposition kinetics of $\mathrm{Li}_{2} \mathrm{~S}$, significantly improving the rate performance and cycle stability of $\mathrm{Li}-\mathrm{S}$ batteries. With $\mathrm{C}-\mathrm{Fe}_{2} \mathrm{O}_{3}-\mathrm{G}$ as the bifunctional electrocatalyst, the assembled batteries delivered a high initial specific capacity of $1521 \mathrm{mAh} \mathrm{g}^{-1}$ at $0.1 \mathrm{C}$ and long-term cycle stability with a low capacity attenuation rate of $0.025 \%$ each cycle for 1600 cycles at $2 \mathrm{C}$. Moreover, a prominent areal capacity of $7.61 \mathrm{mAh} \mathrm{cm}^{-2}$ was maintained under a high sulfur loading of $9.41 \mathrm{mg} \mathrm{cm}^{-2}$ after 85 cycles at $0.2 \mathrm{C}$.

\section{Experimental Section}

\subsection{Synthesis of $\mathrm{C}-\mathrm{Fe}_{2} \mathrm{O}_{3}-\mathrm{G}, \mathrm{P}-\mathrm{Fe}_{2} \mathrm{O}_{3}-\mathrm{G}$ and Reduced Graphene Oxide}

Graphite oxide was synthesized from natural graphite flakes employing a modified Hummers method. Firstly, a graphene oxide (GO) colloidal solution of $5 \mathrm{mg} \mathrm{mL}^{-1}$ was fabricated via a sonication treatment for one hour with $40 \mathrm{mg}$ of GO in 
$8 \mathrm{~mL}$ of deionized water. In a typical synthesis of $\mathrm{C}-\mathrm{Fe}_{2} \mathrm{O}_{3}$ $\mathrm{G}, 1.616 \mathrm{~g}$ of $\mathrm{Fe}\left(\mathrm{NO}_{3}\right)_{3} \cdot 9 \mathrm{H}_{2} \mathrm{O}$ and $0.2 \mathrm{~g}$ of copper acetate were dissolved in deionized water $(12 \mathrm{~mL})$ under magnetic stirring. After twenty minutes, the homogeneous solution was mixed with above-mentioned $8 \mathrm{~mL}$ of GO colloidal solution and continued to be stirred for one hour in ambient atmosphere. Then $20 \mathrm{~mL}$ of ammonia solution ( $25 \mathrm{wt} \%$ ) was quickly added into these mixtures under vigorous stirring and keep stirring for ten minutes. Finally, the resulting mixtures were transferred into a $100-\mathrm{mL}$ Teflon-lined stainless steel autoclave and hydrothermally reacted at $160{ }^{\circ} \mathrm{C}$ for sixteen hours. After cooling down to room temperature naturally, the products were collected by centrifugation and washed with deionized water for several times, and subsequently freezedried at $-50{ }^{\circ} \mathrm{C}$ to obtain $\mathrm{C}-\mathrm{Fe}_{2} \mathrm{O}_{3}$ - $\mathrm{G}$ powder. In the same experimental process, $\mathrm{P}-\mathrm{Fe}_{2} \mathrm{O}_{3}$ - $\mathrm{G}$ was synthesized by replacing copper acetate with nickel acetate and reduced graphene oxide were synthesized without the addition of metal salts.

\subsection{Material Characterization}

The morphologies, structures and elemental estimation of the as-prepared products were performed via the transmission electron microscopy (TEM, FEI Tecnai G2 F30) and scanning electron microscopy (SEM, Hitachi SU8010). The crystal structures of the as-prepared materials were characterized by X-ray diffractometer (PANalytical X'Pert PRO) with $\mathrm{Cu} \mathrm{K \alpha}$ radiation $(40 \mathrm{~mA}, 40 \mathrm{kV})$. The contents of different components were measured by a thermogravimetric analyzer system (Linseis STA PT 1600). The specific surface areas and pore size distribution of the synthesized materials was explored by the Brunauer-Emmett-Teller (BET) method (using ASAP 2020, Micromeritics). X-ray photoelectron spectroscopy (XPS) measurements were taken on Thermo Scientific X-ray photoelectron spectrometer. The UV-Vis analysis was conducted with a Shimadzu UV-2450 spectrophotometer.

More details of other syntheses and characterizations can be seen in Supporting Information.

\section{Results and Discussion}

\subsection{Characterization of $\mathrm{C}-\mathrm{Fe}_{2} \mathrm{O}_{3}-\mathrm{G}$ and $\mathrm{P}-\mathrm{Fe}_{2} \mathrm{O}_{3}-\mathrm{G}$}

$\mathrm{C}-\mathrm{Fe}_{2} \mathrm{O}_{3}$ and $\mathrm{P}-\mathrm{Fe}_{2} \mathrm{O}_{3}$ with different exposed facets supported on the conductive reduced graphene oxide were synthesized by a template-free hydrothermal strategy. The reduced graphene oxide $(G)$ interspersed among nanocrystals not only served for a favorable conductive network but also acted as growth matrix to block the aggregation of $\mathrm{Fe}_{2} \mathrm{O}_{3}$ nanocrystals. The morphology and structure characterizations of $\mathrm{C}-\mathrm{Fe}_{2} \mathrm{O}_{3}-\mathrm{G}$ and $\mathrm{P}-\mathrm{Fe}_{2} \mathrm{O}_{3}-\mathrm{G}$ are shown in Figs. 1 and S1-S3. As shown in the scanning electron microscope (SEM) images (Fig. S1), the dispersity of C- $\mathrm{Fe}_{2} \mathrm{O}_{3}-\mathrm{G}$ and $\mathrm{P}-\mathrm{Fe}_{2} \mathrm{O}_{3}-\mathrm{G}$ is almost identical, and $\mathrm{C}-\mathrm{Fe}_{2} \mathrm{O}_{3}$ and $\mathrm{P}-\mathrm{Fe}_{2} \mathrm{O}_{3}$ were both uniformly interspersed on G. The higher-resolution SEM images (Fig. 1a, e) showed that the sizes of $\mathrm{C}-\mathrm{Fe}_{2} \mathrm{O}_{3}$ and $\mathrm{P}-\mathrm{Fe}_{2} \mathrm{O}_{3}$ were similar, and both average edge lengths (the distance between adjacent corners) of two kinds of nanocrystals were estimated to be approximately $300 \mathrm{~nm}$. However, the morphological difference between $\mathrm{C}-\mathrm{Fe}_{2} \mathrm{O}_{3}$ and $\mathrm{P}-\mathrm{Fe}_{2} \mathrm{O}_{3}$ was obvious. The careful observation of the individual $\mathrm{Fe}_{2} \mathrm{O}_{3}$ nanocrystals at different tilting angles clearly reveals that the shape of $\mathrm{C}-\mathrm{Fe}_{2} \mathrm{O}_{3}$ was concave nanocube (Fig. S2) while the shape of $\mathrm{P}-\mathrm{Fe}_{2} \mathrm{O}_{3}$ was pseudocubic (Fig. S3). The reason that the shape of $\mathrm{P}-\mathrm{Fe}_{2} \mathrm{O}_{3}$ was called as pseudocubic is that its dihedral angles between adjacent flat facets were $94^{\circ}$ or $86^{\circ}$ (Fig. S3a) [38].

In order to accurately confirm the morphology of $\mathrm{C}-\mathrm{Fe}_{2} \mathrm{O}_{3}$ and $\mathrm{P}-\mathrm{Fe}_{2} \mathrm{O}_{3}$ and analyze their exposed crystal facets, transmission electron microscope (TEM) was employed to characterize their fine structure and surface features. The TEM image of a single $\mathrm{C}-\mathrm{Fe}_{2} \mathrm{O}_{3}$ observed along the [2 $\overline{2} 01$ ] direction is shown in Fig. $1 \mathrm{~b}$, and the direction of observation was confirmed by the matching select area electron diffraction (SAED) pattern (Fig. 1c), which indicated the single-crystalline nature of $\mathrm{C}-\mathrm{Fe}_{2} \mathrm{O}_{3}$ [38, 47, 48]. A darker contrast in the middle of the nanocrystal than at its margins is obviously viewed in Fig. 1b, verifying the formation of concave structures. This phenomenon was not shown in TEM images of monocrystalline $\mathrm{P}-\mathrm{Fe}_{2} \mathrm{O}_{3}$ observed along same direction (Fig. 1f, g), which was consistent with the formation of pseudocubic enclosed by six equivalent $\{01 \overline{1} 2\}$ facets (Fig. S4a). In particular, the top view of $\mathrm{C}-\mathrm{Fe}_{2} \mathrm{O}_{3}$ projected along the [2201] direction was shown as an approximate concave octagon, which was further proved the formation of the concave surfaces. In comparison with the quadrangular projection drawing of $\mathrm{P}-\mathrm{Fe}_{2} \mathrm{O}_{3}$ (Fig. 1f), the projected concave octagon of $\mathrm{C}-\mathrm{Fe}_{2} \mathrm{O}_{3}$ could perfectly encircle a smaller quadrilateral as marked by the white dotted line in 

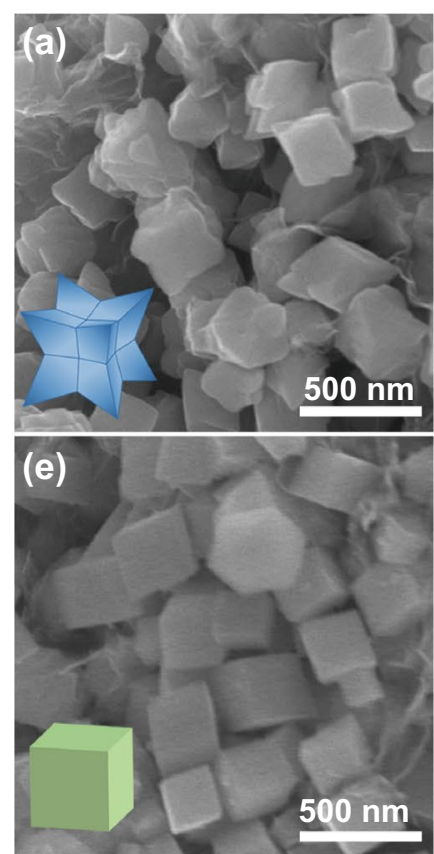

(i)

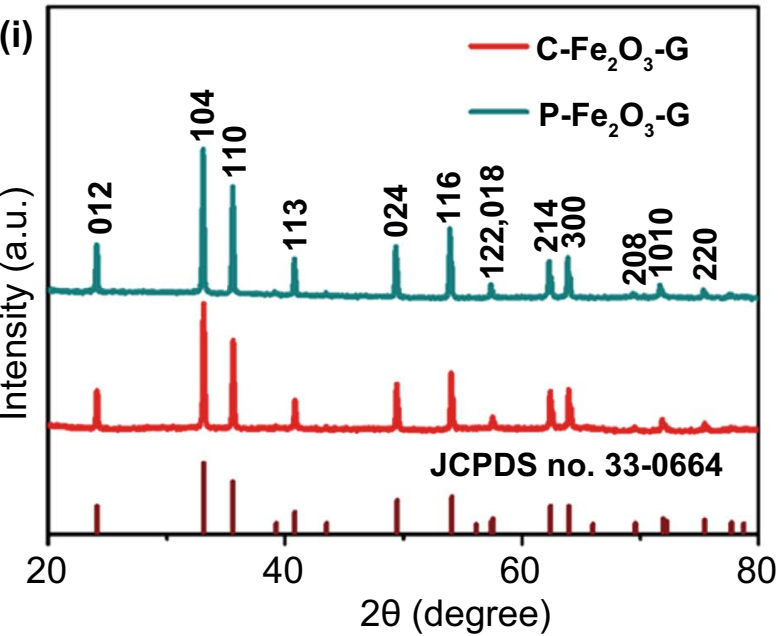

(f)

$86^{\circ}$
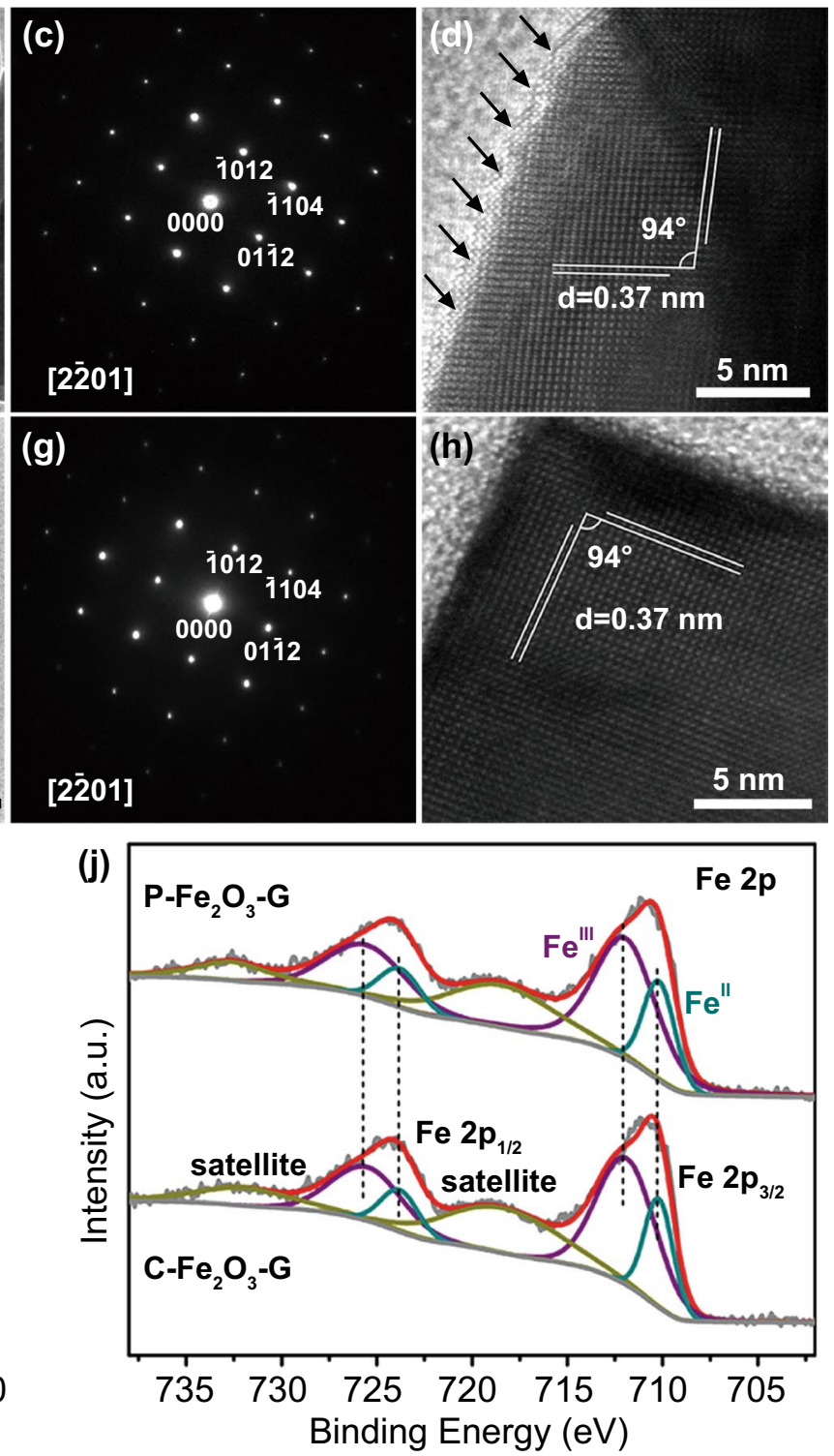

Fig. 1 a SEM image, b TEM image, $\mathbf{c}$ corresponding SAED pattern and $\mathbf{d}$ HRTEM image of $\mathrm{C}^{-} \mathrm{Fe}_{2} \mathrm{O}_{3}$-G. e SEM image, $\mathbf{f}$ TEM image, $\mathbf{g}$ corresponding SAED pattern and $\mathbf{h}$ HRTEM image of $\mathrm{P}-\mathrm{Fe}_{2} \mathrm{O}_{3}$-G. i XRD patterns and $\mathbf{j}$ Fe 2p XPS spectrums of $\mathrm{C}-\mathrm{Fe}_{2} \mathrm{O}_{3}-\mathrm{G}$ and P-Fe $\mathrm{O}_{3}-\mathrm{G}$. The insets in $\mathbf{a}$ and $\mathbf{e}$ are the schematic models of $\mathrm{C}-\mathrm{Fe}_{2} \mathrm{O}_{3}$ and $\mathrm{P}-\mathrm{Fe}_{2} \mathrm{O}_{3}$, respectively

Fig. 1b. In addition, as shown in the high-resolution TEM (HRTEM) image acquired from a concave edge of $\mathrm{C}-\mathrm{Fe}_{2} \mathrm{O}_{3}$ (Fig. 1d), the interplanar spacings of crossed lattice fringes with an intersection angle of $94^{\circ}$ were all $0.37 \mathrm{~nm}$, which corresponded well to the two adjacent $(01 \overline{1} 2)$ and $(\overline{1} 012)$ facets exposed on an individual $\mathrm{P}-\mathrm{Fe}_{2} \mathrm{O}_{3}$ (Fig. 1h) [49-51]. Based on the above analysis, the concave nanocube could be evolved from the pseudocubic [50], and then, the exposed crystal planes of $\mathrm{C}-\mathrm{Fe}_{2} \mathrm{O}_{3}$ were indexed as $\{13 \overline{4} 4\}$ and $\{12 \overline{3} 8\}$ facets by a series of analyses with the help of geometric models and theoretical formulas (Fig. S4b).

The X-ray powder diffraction (XRD) analysis of $\mathrm{C}-\mathrm{Fe}_{2} \mathrm{O}_{3}$ $\mathrm{G}$ and $\mathrm{P}-\mathrm{Fe}_{2} \mathrm{O}_{3}-\mathrm{G}$ clearly showed that all of the diffraction peaks could be indexed to $\alpha-\mathrm{Fe}_{2} \mathrm{O}_{3}$ (JCPDS no. 33-0664), which indicated that both of them not only had a high purity but also belonged to the same space group (Fig. 1i). Due 
to the reduction of $\mathrm{GO}$ to $\mathrm{G}$, the characteristic diffraction peak at $10.4^{\circ}$ of $\mathrm{GO}$ was not detected in $\mathrm{C}-\mathrm{Fe}_{2} \mathrm{O}_{3}-\mathrm{G}$ and $\mathrm{P}^{-} \mathrm{Fe}_{2} \mathrm{O}_{3}$-G (Fig. S5) [52, 53]. These component identification results were in agreement with the Raman spectra analysis (Fig. S6). The mass ratios of $\mathrm{G}$ to oxide in $\mathrm{C}-\mathrm{Fe}_{2} \mathrm{O}_{3}$ $\mathrm{G}$ and $\mathrm{P}-\mathrm{Fe}_{2} \mathrm{O}_{3}-\mathrm{G}$ were investigated by thermogravimetric analysis (TGA), and the TG curves of them are shown in Fig. S7. The slight weight loss in the initial phase was due to the elimination of the absorbed water on these nanocomposites. Then the significant weight loss appeared on two TG curves, indicating oxidative decomposition of $\mathrm{G}$ [53]. Apparently, the mass ratios of $\mathrm{G}$ in $\mathrm{C}-\mathrm{Fe}_{2} \mathrm{O}_{3}-\mathrm{G}$ and $\mathrm{P}-\mathrm{Fe}_{2} \mathrm{O}_{3}-\mathrm{G}$ were equivalent and the $\mathrm{G}$ contents in two composites were both approximately 10.9 wt $\%$, which was consistent with the theoretical calculation value. The Brunauer-Emmett-Teller (BET) specific surface areas of $\mathrm{C}-\mathrm{Fe}_{2} \mathrm{O}_{3}-\mathrm{G}$ and $\mathrm{P}-\mathrm{Fe}_{2} \mathrm{O}_{3}-\mathrm{G}$ were calculated using $\mathrm{N}_{2}$ adsorption-desorption isotherms, which were $19.71 \mathrm{~m}^{2} \mathrm{~g}^{-1}$ and $20.16 \mathrm{~m}^{2} \mathrm{~g}^{-1}$ (Fig. S8). Based on the above analysis and exclude unimportant factors, the crystal facet effect on sulfur species between C- $\mathrm{Fe}_{2} \mathrm{O}_{3}-\mathrm{G}$ and $\mathrm{P}-\mathrm{Fe}_{2} \mathrm{O}_{3}-\mathrm{G}$ could be researched systematically.

In general, the adsorption properties and catalytic activity of materials are closely related to their surface environment (chemical composition, element valence and structural characteristics) [33, 37, 40, 49, 54, 55]. X-ray photoelectron spectroscopy (XPS) survey spectrums of $\mathrm{C}-\mathrm{Fe}_{2} \mathrm{O}_{3}-\mathrm{G}$ and $\mathrm{P}-\mathrm{Fe}_{2} \mathrm{O}_{3}-\mathrm{G}$ confirmed similar elemental compositions, while the states of some constituent elements are different. The high-resolution $\mathrm{Fe} 2 \mathrm{p}$ spectrums of $\mathrm{C}-\mathrm{Fe}_{2} \mathrm{O}_{3}-\mathrm{G}$ and $\mathrm{P}-\mathrm{Fe}_{2} \mathrm{O}_{3}$ $\mathrm{G}$ both displayed two major peaks at 711 and $724.4 \mathrm{eV}$ (Fig. 1j), ascribed to the typical Fe $2 p_{3 / 2}$ and $\mathrm{Fe} 2 \mathrm{p}_{1 / 2}$ orbitals, respectively $[49,52]$. Each major peak could be decomposed into two fitted Gaussian components, corresponding to $\mathrm{Fe}^{3+}$ and $\mathrm{Fe}^{2+}$ species, respectively $[56,57]$. The $\mathrm{Fe}^{2+}$ / $\mathrm{Fe}^{3+}$ ratio of $\mathrm{C}-\mathrm{Fe}_{2} \mathrm{O}_{3}-\mathrm{G}$ was estimated to be higher than $\mathrm{P}-\mathrm{Fe}_{2} \mathrm{O}_{3}-\mathrm{G}$ based on the integrated areas of the $\mathrm{Fe}^{2+} 2 \mathrm{p}_{3 / 2}$ and $\mathrm{Fe}^{3+} 2 \mathrm{p}_{3 / 2}$ peaks. It indicated that there are more unsaturated coordinated $\mathrm{Fe}$ sites existed on the surface of $\mathrm{C}-\mathrm{Fe}_{2} \mathrm{O}_{3}$ with abundant step atoms (the surface atom arrangements of different crystal planes are shown in Figs. 1d, $h$ and S9) [58]. Corresponding to the theoretical simulation (Fig. S10), the coordination analysis of $\mathrm{Fe}$ atoms on different crystallographic planes revealed that $\mathrm{Fe}_{2} \mathrm{O}_{3}(13 \overline{4} 4)$ and $(12 \overline{3} 8)$ facets possessed more unsaturated coordinated $\mathrm{Fe}$ atoms with dangling bonds in comparison with $\mathrm{Fe}_{2} \mathrm{O}_{3}(01 \overline{1} 2)$ facet.

\subsection{Comparison of LiPS Adsorption}

It is well known that the chemical adsorption of LiPSs is the precondition for their further conversion reactions on the electrocatalyst [33]. Benefiting from the unstable highindex facets with abundant unsaturated coordinated $\mathrm{Fe}$ sites, $\mathrm{C}-\mathrm{Fe}_{2} \mathrm{O}_{3}-\mathrm{G}$ should have a stronger adsorption capacity for LiPSs than $\mathrm{P}-\mathrm{Fe}_{2} \mathrm{O}_{3}$-G. DFT calculations were executed to appraise the ability to anchor LiPSs of $\mathrm{C}-\mathrm{Fe}_{2} \mathrm{O}_{3}-\mathrm{G}$ and $\mathrm{P}-\mathrm{Fe}_{2} \mathrm{O}_{3}-\mathrm{G}$ (Fig. 2a-c). The binding energies $\left(E_{\mathrm{b}}\right)$ between different exposed crystal facets of two kinds $\mathrm{Fe}_{2} \mathrm{O}_{3}$ and $\mathrm{Li}_{2} \mathrm{~S}_{4}$ were remarkably different, calculated via a formula $\left(E_{\mathrm{b}}=E_{\mathrm{Li} 2 \mathrm{~S} 4+\text { crystal facet }}-E_{\text {crystal facet }}-E_{\mathrm{Li2S} 4}\right)$ [59]. The bind-

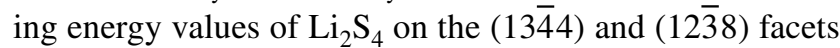
of $\mathrm{C}-\mathrm{Fe}_{2} \mathrm{O}_{3}$ were -1.50 and $-1.18 \mathrm{eV}$, which were more negative than on the $(01 \overline{1} 2)$ facets of $\mathrm{P}^{-} \mathrm{Fe}_{2} \mathrm{O}_{3}(-0.82 \mathrm{eV})$. Therefore, $\mathrm{C}-\mathrm{Fe}_{2} \mathrm{O}_{3}-\mathrm{G}$ could anchor $\mathrm{Li}_{2} \mathrm{~S}_{4}$ more efficiently than $\mathrm{P}-\mathrm{Fe}_{2} \mathrm{O}_{3}-\mathrm{G}$, owing to the more negative binding energy value signifies a stronger immobilizing effect toward $\mathrm{Li}_{2} \mathrm{~S}_{4}$ $[9,28,29]$.

To further validate the stronger interaction between $\mathrm{C}-\mathrm{Fe}_{2} \mathrm{O}_{3}-\mathrm{G}$ and LiPSs, the visualized adsorption experiments were performed by adding $\mathrm{C}-\mathrm{Fe}_{2} \mathrm{O}_{3}-\mathrm{G}$ or $\mathrm{P}-\mathrm{Fe}_{2} \mathrm{O}_{3}$ $\mathrm{G}$ or $\mathrm{G}$ with the same mass into the $\mathrm{Li}_{2} \mathrm{~S}_{4}$ solution. As shown in Fig. 2 d, the $\mathrm{Li}_{2} \mathrm{~S}_{4}$ solution with $\mathrm{C}-\mathrm{Fe}_{2} \mathrm{O}_{3}-\mathrm{G}$ was almost completely faded after static adsorption for $5 \mathrm{~h}$, whereas the $\mathrm{Li}_{2} \mathrm{~S}_{4}$ solutions containing $\mathrm{P}-\mathrm{Fe}_{2} \mathrm{O}_{3}-\mathrm{G}$ or $\mathrm{G}$ still remained gradually deepened yellow. The UV/Vis spectrums of these solutions after aging exhibited that more $\mathrm{Li}_{2} \mathrm{~S}_{4}$ were adsorbed by $\mathrm{C}-\mathrm{Fe}_{2} \mathrm{O}_{3}-\mathrm{G}$ than others, indicating a superior binding capability toward LiPSs of $\mathrm{C}-\mathrm{Fe}_{2} \mathrm{O}_{3}-\mathrm{G}$ than $\mathrm{P}-\mathrm{Fe}_{2} \mathrm{O}_{3}-\mathrm{G}$ and $\mathrm{G}$ (Fig. 2e). The visualized adsorption experiments of $\mathrm{Li}_{2} \mathrm{~S}_{6}$ displayed the same results (Fig. S11), which further visually demonstrated the superiority of $\mathrm{C}-\mathrm{Fe}_{2} \mathrm{O}_{3}-\mathrm{G}$ in adsorbing LiPSs. In addition, XPS analyses of C- $\mathrm{Fe}_{2} \mathrm{O}_{3}-\mathrm{G}$ and $\mathrm{P}-\mathrm{Fe}_{2} \mathrm{O}_{3}-\mathrm{G}$ dried after $\mathrm{Li}_{2} \mathrm{~S}_{4}$ adsorption (C- $\mathrm{Fe}_{2} \mathrm{O}_{3}-\mathrm{G}-\mathrm{Li}_{2} \mathrm{~S}_{4}$ and $\mathrm{P}-\mathrm{Fe}_{2} \mathrm{O}_{3}-\mathrm{G}-\mathrm{Li}_{2} \mathrm{~S}_{4}$ ) were performed to further reveal the chemical interaction toward $\mathrm{Li}_{2} \mathrm{~S}_{4}$ between $\mathrm{C}-\mathrm{Fe}_{2} \mathrm{O}_{3}-\mathrm{G}$ and $\mathrm{P}-\mathrm{Fe}_{2} \mathrm{O}_{3}$-G (Fig. 2f). In comparison with pristine nanocomposites without $\mathrm{Li}_{2} \mathrm{~S}_{4}$, the four characteristic peaks of $\mathrm{Fe}^{2+} 2 \mathrm{p}_{3 / 2}, \mathrm{Fe}^{2+} 2 \mathrm{p}_{1 / 2}, \mathrm{Fe}^{3+} 2 \mathrm{p}_{3 / 2}$ and $\mathrm{Fe}^{3+}$ $2 p_{1 / 2}$ overall shifted toward lower binding energies (Fig. 2f), implying the strong chemical interaction between $\mathrm{Li}_{2} \mathrm{~S}_{4}$ and two nanocomposites [60]. Since the four characteristic peaks of $\mathrm{C}-\mathrm{Fe}_{2} \mathrm{O}_{3}$-G located at the same position as those corresponding characteristic peaks of $\mathrm{P}-\mathrm{Fe}_{2} \mathrm{O}_{3}-\mathrm{G}$ as shown in 
(a)
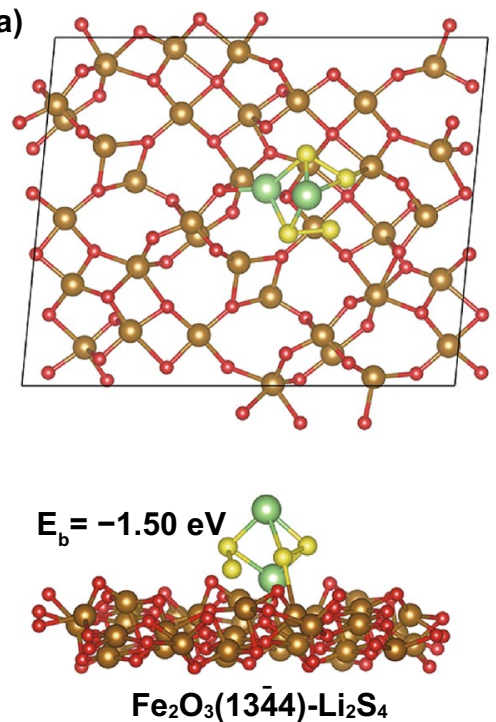

(d)

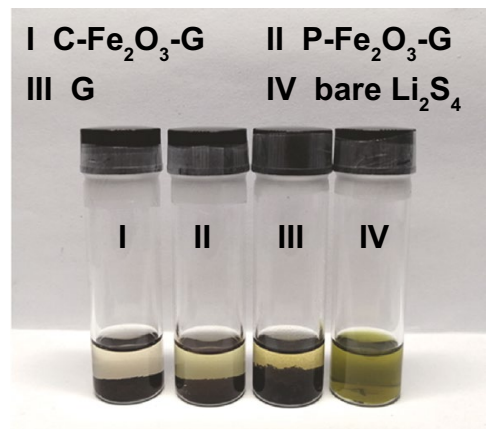

(b)
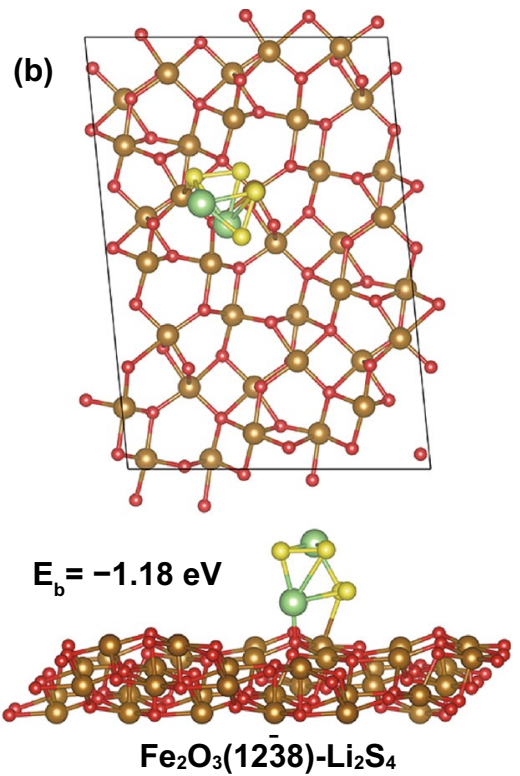

(e)

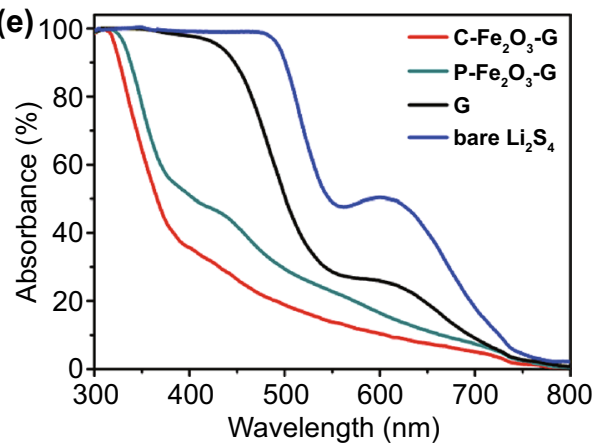

(c)
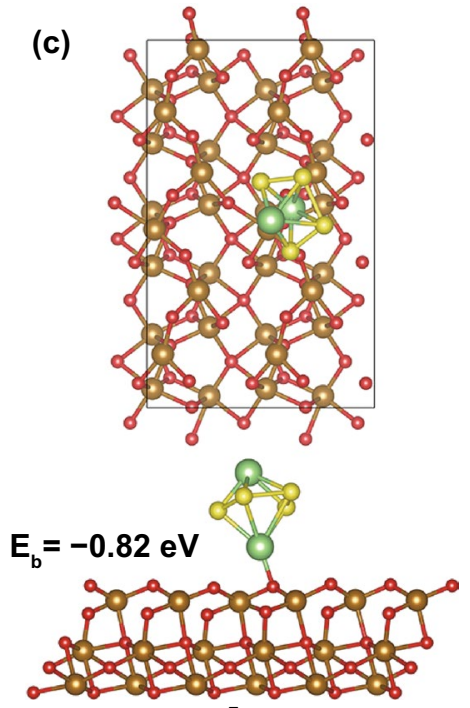

$\mathrm{Fe}_{2} \mathrm{O}_{3}(0112)-\mathrm{Li}_{2} \mathrm{~S}_{4}$

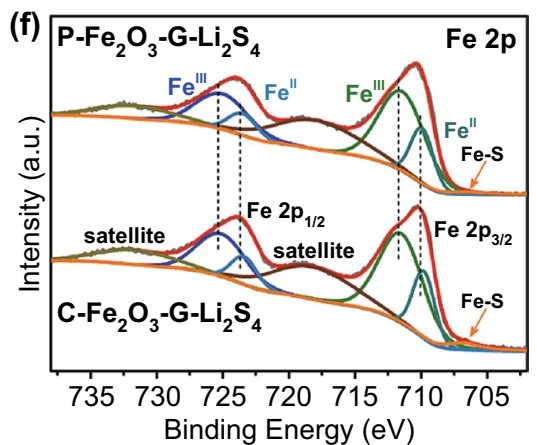

Fig. 2 a-c Optimized geometries of $\mathrm{Li}_{2} \mathrm{~S}_{4}$ adsorbed on different $\mathrm{Fe}_{2} \mathrm{O}_{3}$ crystal facets. d Optical photograph and e UV-Vis spectrums of a bare $\mathrm{Li}_{2} \mathrm{~S}_{4}$ solution and the $\mathrm{Li}_{2} \mathrm{~S}_{4}$ solutions with different materials after static adsorption for $5 \mathrm{~h}$. $\mathbf{f ~ F e} 2 \mathrm{p} \mathrm{XPS}$ comparative analysis of C-Fe $\mathrm{O}_{3}-\mathrm{G}$ and $\mathrm{P}-\mathrm{Fe}_{2} \mathrm{O}_{3}$-G after interacting with $\mathrm{Li}_{2} \mathrm{~S}_{4}$

Figs. $1 \mathrm{j}$ and $\mathrm{S} 12$, it was easy to observe the shift gaps of $\mathrm{Fe}^{2+}$ 2p peaks between $\mathrm{C}-\mathrm{Fe}_{2} \mathrm{O}_{3}-\mathrm{G}-\mathrm{Li}_{2} \mathrm{~S}_{4}$ and $\mathrm{P}-\mathrm{Fe}_{2} \mathrm{O}_{3}-\mathrm{G}-\mathrm{Li}_{2} \mathrm{~S}_{4}$ (Fig. 2f). These shift gaps indicated the stronger chemical interaction between $\mathrm{Fe}^{2+} 2 \mathrm{p}$ sites on $\mathrm{C}-\mathrm{Fe}_{2} \mathrm{O}_{3}-\mathrm{G}$ and $\mathrm{Li}_{2} \mathrm{~S}_{4}$ than those on $\mathrm{P}-\mathrm{Fe}_{2} \mathrm{O}_{3}-\mathrm{G}$, which was attributed to the more $\mathrm{Fe}^{2+}$ sites that have interacted with $\mathrm{S}_{\mathrm{x}}{ }^{2-}$ on the surface of $\mathrm{C}-\mathrm{Fe}_{2} \mathrm{O}_{3}-\mathrm{G}$, namely the exposed high-index $\{12 \overline{3} 8\}$ and $\{13 \overline{4} 4\}$ crystal facets on $\mathrm{C}-\mathrm{Fe}_{2} \mathrm{O}_{3}-\mathrm{G}$ provided more unsaturated coordinated $\mathrm{Fe}^{2+}$ sites, leading to the more effective bonding of $\mathrm{S}_{\mathrm{x}}{ }^{2-}$. Noteworthy, a distinct additional peak representative of $\mathrm{Fe}-\mathrm{S}$ bond was appeared at $706.7 \mathrm{eV}$ in $\mathrm{Fe}$ $2 \mathrm{p}$ spectrum of $\mathrm{C}-\mathrm{Fe}_{2} \mathrm{O}_{3}-\mathrm{G}-\mathrm{Li}_{2} \mathrm{~S}_{4}$, while this characteristic peak of $\mathrm{Fe}-\mathrm{S}$ bond in $\mathrm{Fe} 2 \mathrm{p}$ spectrum of $\mathrm{P}-\mathrm{Fe}_{2} \mathrm{O}_{3}-\mathrm{G}-\mathrm{Li}_{2} \mathrm{~S}_{4}$ was significantly smaller (Fig. 2f), which further confirmed the stronger $\mathrm{Fe}-\mathrm{S}$ interactions between $\mathrm{C}-\mathrm{Fe}_{2} \mathrm{O}_{3}-\mathrm{G}$ and
$\mathrm{Li}_{2} \mathrm{~S}_{4}$ than $\mathrm{P}-\mathrm{Fe}_{2} \mathrm{O}_{3}-\mathrm{G}[52,57]$. Furthermore, the stronger $\mathrm{Fe}-\mathrm{S}$ bond and more obvious forward movement of the terminal sulfur $\left(\mathrm{S}_{\mathrm{T}}{ }^{-1}\right)$ were showed in S 2p XPS spectrum of C- $\mathrm{Fe}_{2} \mathrm{O}_{3}-\mathrm{G}-\mathrm{Li}_{2} \mathrm{~S}_{4}$ compared with those of $\mathrm{P}-\mathrm{Fe}_{2} \mathrm{O}_{3}-\mathrm{G}-\mathrm{Li}_{2} \mathrm{~S}_{4}$, which also demonstrated the stronger adsorption capacity of $\mathrm{C}-\mathrm{Fe}_{2} \mathrm{O}_{3}-\mathrm{G}$ for LiPSs (Fig. S 13) [26].

\subsection{Evaluation of Catalytic Activity}

In order to gain insight into the efficacy of high-index faceted catalysts in accelerating the liquid-liquid conversion of LiPSs, the redox reaction kinetics of LiPSs were systemically analyzed by cyclic voltammetry (CV) experiments for the $\mathrm{Li}_{2} \mathrm{~S}_{6}$ symmetric batteries (Fig. 3a), which were assembled by sandwiching commercialized polypropylene 

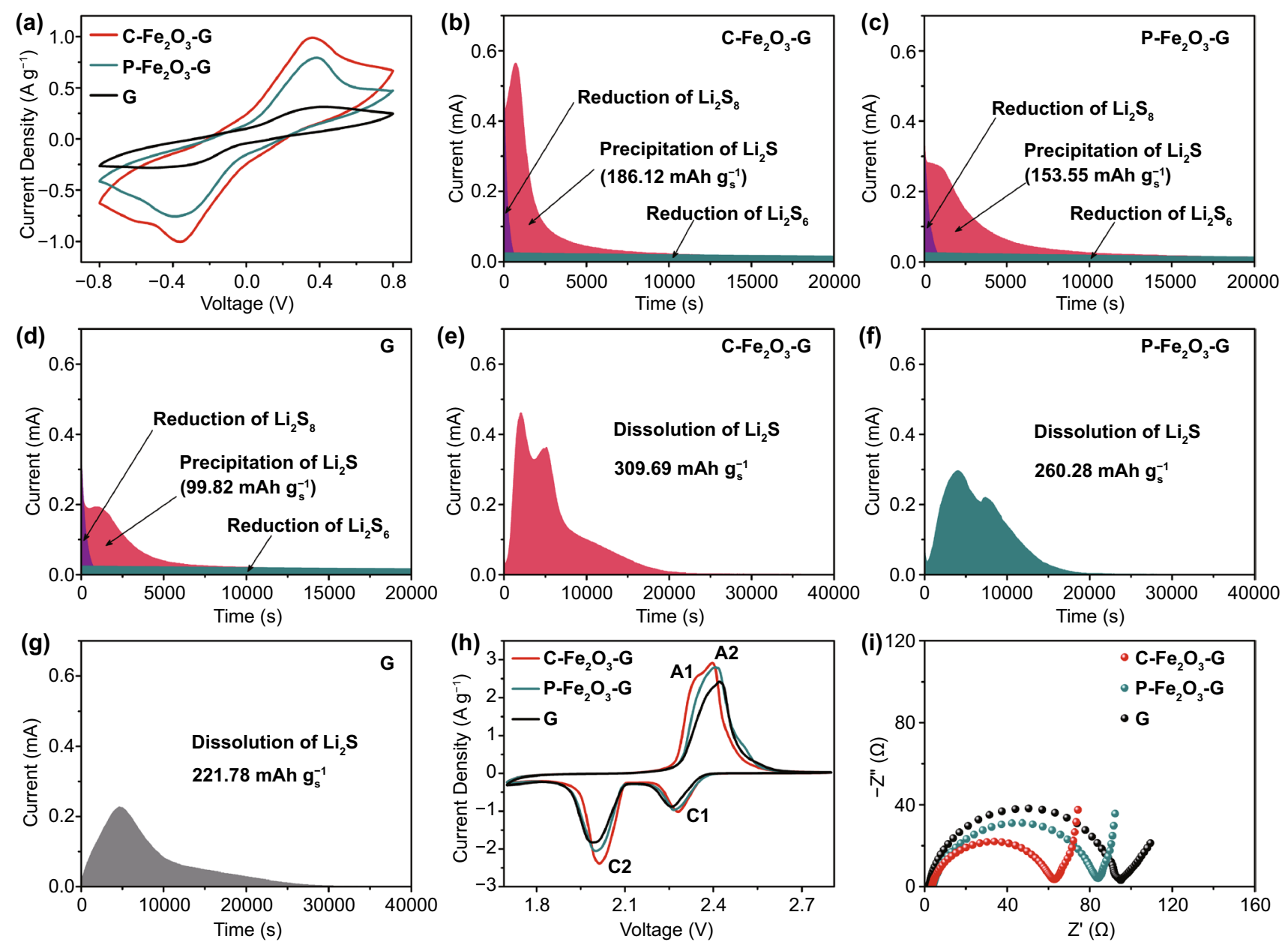

Fig. 3 a CV curves of the symmetric batteries with $\mathrm{C}-\mathrm{Fe}_{2} \mathrm{O}_{3}-\mathrm{G}, \mathrm{P}-\mathrm{Fe}_{2} \mathrm{O}_{3}-\mathrm{G}$ and $\mathrm{G}$ electrodes. Potentiostatic discharge profiles of $\mathrm{Li} \mathrm{S}_{2} \mathrm{~S}$ nucleation on $\mathbf{b} \mathrm{C}-\mathrm{Fe}_{2} \mathrm{O}_{3}-\mathrm{G}$, $\mathbf{c} \mathrm{P}-\mathrm{Fe}_{2} \mathrm{O}_{3}-\mathrm{G}$ and $\mathbf{d}$ G. Potentiostatic charge profile of $\mathrm{Li}_{2} \mathrm{~S}$ dissolution on e $\mathrm{C}-\mathrm{Fe}_{2} \mathrm{O}_{3}-\mathrm{G}, \mathbf{f} \mathrm{P}-\mathrm{Fe}_{2} \mathrm{O}_{3}-\mathrm{G}$ and $\mathbf{g} \mathrm{G}$. $\mathbf{h} \mathrm{CV}$ curves and i corresponding Nyquist plots of asymmetrical batteries with $\mathrm{C}-\mathrm{Fe}_{2} \mathrm{O}_{3}-\mathrm{G}, \mathrm{P}-\mathrm{Fe}_{2} \mathrm{O}_{3}-\mathrm{G}$ and $\mathrm{G}$

(PP) membrane between two same sulfur-free electrodes and filled with $\mathrm{Li}_{2} \mathrm{~S}_{6}$ electrolyte. Obviously, the CV curve of $\mathrm{Li}_{2} \mathrm{~S}_{6}$ symmetric battery with $\mathrm{C}-\mathrm{Fe}_{2} \mathrm{O}_{3}$-G electrodes displayed a higher polarization current than those with $\mathrm{P}-\mathrm{Fe}_{2} \mathrm{O}_{3}-\mathrm{G}$ and $\mathrm{G}$ electrodes under a scan rate of $5 \mathrm{mV} \mathrm{s}^{-1}$, implying that $\mathrm{C}-\mathrm{Fe}_{2} \mathrm{O}_{3}-\mathrm{G}$ had significantly stronger effectiveness in enhancing the redox kinetics between liquidphase LiPSs [59].

In comparison with the liquid-liquid conversion of LiPSs, the liquid-solid-liquid conversion involving the nucleation and decomposition of $\mathrm{Li}_{2} \mathrm{~S}$ could control the sulfur utilization and specific capacity of $\mathrm{Li}-\mathrm{S}$ batteries more effectively [61]. Therefore, it was important to evaluate the catalytic effect for the deposition and dissolution of $\mathrm{Li}_{2} \mathrm{~S}$ by catalyst material [61]. To investigate the $\mathrm{Li}_{2} \mathrm{~S}$ precipitation process, simple potentiostatic discharge experiments of $\mathrm{C}-\mathrm{Fe}_{2} \mathrm{O}_{3}-\mathrm{G}$, $\mathrm{P}-\mathrm{Fe}_{2} \mathrm{O}_{3}-\mathrm{G}$ and $\mathrm{G}$ electrodes were executed (Fig. 3b-d). The $\mathrm{C}-\mathrm{Fe}_{2} \mathrm{O}_{3}-\mathrm{G}$ electrode took less time to reach a higher current peak of $0.57 \mathrm{~mA}$ than $\mathrm{P}-\mathrm{Fe}_{2} \mathrm{O}_{3}$-G electrode and $\mathrm{G}$ electrode under $2.05 \mathrm{~V}$. Meanwhile, the capacity of $\mathrm{Li}_{2} \mathrm{~S}$ precipitation on $\mathrm{C}-\mathrm{Fe}_{2} \mathrm{O}_{3}-\mathrm{G}\left(186.12 \mathrm{mAh} \mathrm{g}^{-1}\right)$ was higher than those on $\mathrm{P}-\mathrm{Fe}_{2} \mathrm{O}_{3}-\mathrm{G}\left(153.55 \mathrm{mAh} \mathrm{g}^{-1}\right)$ and $\mathrm{G}\left(99.82 \mathrm{mAh} \mathrm{g}^{-1}\right)$. The above results demonstrated that $\mathrm{C}-\mathrm{Fe}_{2} \mathrm{O}_{3}-\mathrm{G}$ could markedly facilitate $\mathrm{Li}_{2} \mathrm{~S}$ nucleation and deposition amounts. In addition, the similar kinetic studies were performed via a potentiostatic decompositions after the galvanostatic discharge processes to verify the superiority of $\mathrm{C}-\mathrm{Fe}_{2} \mathrm{O}_{3}-\mathrm{G}$ for boosting the dissolution of deposited $\mathrm{Li}_{2} \mathrm{~S}$. As shown in Fig. 3e-g, both the oxidation current density and $\mathrm{Li}_{2} \mathrm{~S}$ dissolution capacity of $\mathrm{C}-\mathrm{Fe}_{2} \mathrm{O}_{3}-\mathrm{G}$ electrode were higher 
compared to those of $\mathrm{P}-\mathrm{Fe}_{2} \mathrm{O}_{3}-\mathrm{G}$ and $\mathrm{G}$ electrodes, revealing that $\mathrm{C}-\mathrm{Fe}_{2} \mathrm{O}_{3}-\mathrm{G}$ could reduce the oxidation overpotential and enhance the kinetics of $\mathrm{Li}_{2} \mathrm{~S}$ dissolution and conversion more effectively than the other two materials during charging $[33,59,61]$.

\subsection{Comparison of Electrochemical Performance}

To evaluate the practical superiority of $\mathrm{C}-\mathrm{Fe}_{2} \mathrm{O}_{3}-\mathrm{G}$ for enhancing the electrochemical kinetics of LiPS transformation in a working $\mathrm{Li}-\mathrm{S}$ battery, $\mathrm{C}-\mathrm{Fe}_{2} \mathrm{O}_{3}-\mathrm{G}, \mathrm{P}-\mathrm{Fe}_{2} \mathrm{O}_{3}-\mathrm{G}$ and $\mathrm{G}$ with the same mass were coated on the commercial PP membranes to obtain the functionalized separators. In Fig. S14, C- $-\mathrm{Fe}_{2} \mathrm{O}_{3}$ - $\mathrm{G}$ and $\mathrm{P}-\mathrm{Fe}_{2} \mathrm{O}_{3}$-G adhered evenly on the PP membrane surface to assemble the faultless interlayers with a thickness of $15 \mu \mathrm{m}$. And then, the accelerated redox reactions of sulfur species transformation were explored by $\mathrm{CV}$ measurements of $\mathrm{Li}-\mathrm{S}$ batteries assembled with these functionalized separators between C-S cathodes (Fig. S15) and $\mathrm{Li}$ metal anodes at $0.1 \mathrm{mV} \mathrm{s}^{-1}$. The $\mathrm{CV}$ curves recorded within a voltage window of 1.7-2.8 $\mathrm{V}$ all obviously exhibited the cathodic (reduction) peaks and anodic (oxidation) peaks, which respectively corresponded to the reduction of sulfur to soluble LiPSs [29], LiPSs to $\mathrm{Li}_{2} \mathrm{~S}_{2} / \mathrm{Li}_{2} \mathrm{~S}$ and the oxidation of $\mathrm{Li}_{2} \mathrm{~S}_{2} / \mathrm{Li}_{2} \mathrm{~S}$ to sulfur (Fig. 3h). Obviously, the positive shift of two cathodic peaks to a higher voltage and the negative shift of the anodic peak to a lower voltage, as well as the enhanced current of all redox peaks were exhibited on the cell with $\mathrm{C}-\mathrm{Fe}_{2} \mathrm{O}_{3}-\mathrm{G}$ interlayer $\left(\mathrm{C}-\mathrm{Fe}_{2} \mathrm{O}_{3}-\mathrm{G}\right.$ cell) compared to those with $\mathrm{P}-\mathrm{Fe}_{2} \mathrm{O}_{3}-\mathrm{G}$ and $\mathrm{G}$ interlayers ( $\mathrm{P}-\mathrm{Fe}_{2} \mathrm{O}_{3}-\mathrm{G}$ cell and $\mathrm{G}$ cell), indicating that $\mathrm{C}-\mathrm{Fe}_{2} \mathrm{O}_{3}-\mathrm{G}$ had more robust catalytic ability to enhance the redox kinetics of LiPSs [9-11, 33, 59]. The peculiar A1 peak appeared only on the CV curve of $\mathrm{C}-\mathrm{Fe}_{2} \mathrm{O}_{3}-\mathrm{G}$ cell, which signified a rapider $\mathrm{Li}_{2} \mathrm{~S}$ dissolution behavior on $\mathrm{C}-\mathrm{Fe}_{2} \mathrm{O}_{3}-\mathrm{G}$ than others [29]. Furthermore, in comparison with $\mathrm{P}_{-} \mathrm{Fe}_{2} \mathrm{O}_{3}-\mathrm{G}$ cell and $\mathrm{G}$ cell, the electrochemical impedance spectroscopy (EIS) of $\mathrm{C}-\mathrm{Fe}_{2} \mathrm{O}_{3}-\mathrm{G}$ cell showed the smallest charge transfer resistance, manifesting the superior interfacial charge conductivity under $\mathrm{C}-\mathrm{Fe}_{2} \mathrm{O}_{3}$ - $\mathrm{G}$ electrocatalysis, which resulted in the accelerated sulfur redox kinetics (Fig. 3i).

Subsequently, CV measurements were also implemented under higher scan rates $\left(0.2\right.$ to $\left.0.6 \mathrm{mV} \mathrm{s}^{-1}\right)$ to investigate lithium-ion diffusion coefficients, which were another important impact factor for the transformation kinetics of
LiPSs [61], to confirm the superior electrochemical performance of $\mathrm{C}-\mathrm{Fe}_{2} \mathrm{O}_{3}-\mathrm{G}$ in LiPS conversion. All reduction and oxidation peak currents varied linearly with the square root of scanning rate, and the slopes of the curves obtained from the linear fitting of peak currents were positively interrelated with the corresponding lithium-ion diffusion in cells with different interlayers (Fig. S16). Evidently, $\mathrm{C}-\mathrm{Fe}_{2} \mathrm{O}_{3}-\mathrm{G}$ cell exhibited the largest slope value in each reduction and oxidation reaction of sulfur species, which certified the superiority of $\mathrm{C}-\mathrm{Fe}_{2} \mathrm{O}_{3}-\mathrm{G}$ in accelerating mass transfer and LiPS redox kinetics during discharge/charge [29, 61]. To further demonstrate the faster lithium-ion transport kinetics of the $\mathrm{C}-\mathrm{Fe}_{2} \mathrm{O}_{3}-\mathrm{G}$, the galvanostatic intermittent titration technique (GITT) was employed to analyze the lithium-ion diffusion coefficient $\left(\mathrm{D}_{\mathrm{Li}}{ }^{+}\right)$in three battery systems (Fig. S17a-c). The calculated $\mathrm{D}_{\mathrm{Li}}{ }^{+}$values in $\mathrm{C}-\mathrm{Fe}_{2} \mathrm{O}_{3}$-G cell were larger than those in $\mathrm{P}-\mathrm{Fe}_{2} \mathrm{O}_{3}-\mathrm{G}$ and $\mathrm{G}$ cells (Fig. S17d), further confirming the superiority of $\mathrm{C}-\mathrm{Fe}_{2} \mathrm{O}_{3}-\mathrm{G}$ in accelerating the lithium-ion transfer.

The galvanostatic charge-discharge measurements of the cells with different catalytic materials under $0.1 \mathrm{C}$ also revealed similar results matched with the above analyses. The charge-discharge curves within a cutoff voltage of 1.7-2.8 V showed two discharge plateaus and a charge plateau, respectively, assigning to the reduction and oxidation peaks of CV curves (Fig. 4a). In comparison with $\mathrm{P}-\mathrm{Fe}_{2} \mathrm{O}_{3}-\mathrm{G}$ cell and $\mathrm{G}$ cell, $\mathrm{C}-\mathrm{Fe}_{2} \mathrm{O}_{3}-\mathrm{G}$ cell manifested higher discharge capacity at the first voltage plateau $\left(\mathrm{Q}_{1}\right)$ and second voltage plateau $\left(\mathrm{Q}_{2}\right)$ as well as lager capacity ratio of $\mathrm{Q}_{2}$ to $\mathrm{Q}_{1}$, which not only indicated the superiority in suppressing the shuttling of LiPSs but also verified the stronger catalytic effect in promoting the conversion of LiPSs to unsolvable $\mathrm{Li}_{2} \mathrm{~S}$ [59]. The cell with $\mathrm{C}-\mathrm{Fe}_{2} \mathrm{O}_{3}-\mathrm{G}$ exhibited the smallest polarization $\left(\Delta E_{1}=0.1522 \mathrm{~V}\right)$ than those with $\mathrm{P}-\mathrm{Fe}_{2} \mathrm{O}_{3}-\mathrm{G}$ $\left(\Delta E_{2}=0.1848 \mathrm{~V}\right)$ and $\mathrm{G}\left(\Delta E_{3}=0.2036 \mathrm{~V}\right)$, further proving the enhanced electrochemical kinetics stemming from $\mathrm{C}-\mathrm{Fe}_{2} \mathrm{O}_{3}$-G. In the charge process, the smallest initial charge potential barrier was displayed on the curve of $\mathrm{C}-\mathrm{Fe}_{2} \mathrm{O}_{3}-\mathrm{G}$ cell, which implied a most robust catalytic effect of $\mathrm{C}-\mathrm{Fe}_{2} \mathrm{O}_{3}$ $\mathrm{G}$ in the decomposition of $\mathrm{Li}_{2} \mathrm{~S}$ (Fig. 4b) [33, 59].

To further validate the significant impact of $\mathrm{C}-\mathrm{Fe}_{2} \mathrm{O}_{3}-\mathrm{G}$ on boosting the sulfur redox kinetics, the rate capacities of the batteries assembled with different interlayers were first evaluated under increasing current density from 0.1 to 4.0 $\mathrm{C}$ (Fig. 4c). C- $\mathrm{Fe}_{2} \mathrm{O}_{3}$-G cell exhibited the highest initial discharge capacity of $1521 \mathrm{mAh} \mathrm{g}^{-1}$ at $0.1 \mathrm{C}$ among three 

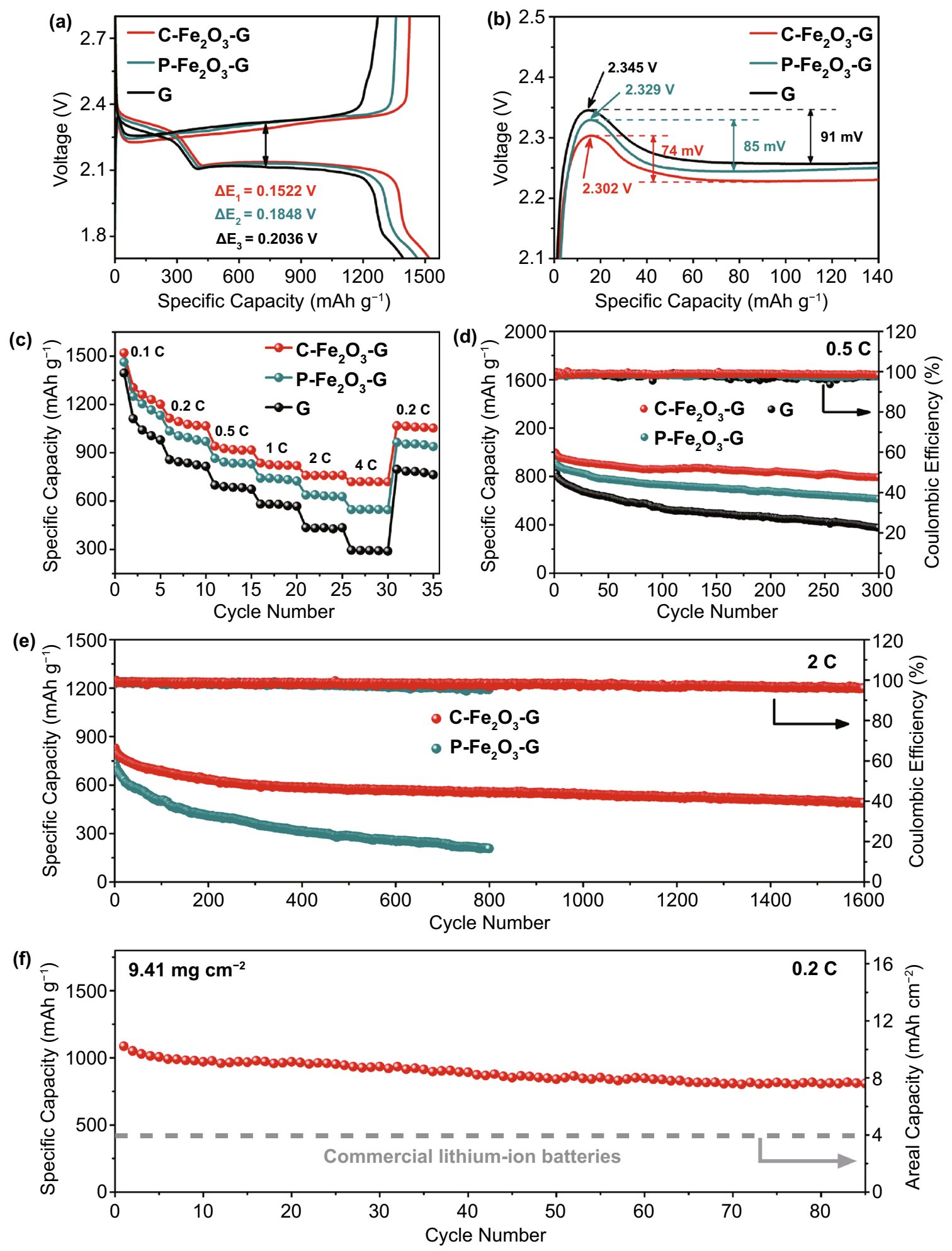

Fig. 4 a Galvanostatic charge/discharge profiles and b charge voltage profiles of $\mathrm{C}-\mathrm{Fe}_{2} \mathrm{O}_{3}-\mathrm{G}, \mathrm{P}-\mathrm{Fe}_{2} \mathrm{O}_{3}-\mathrm{G}$ and $\mathrm{G}$ cells at $0.1 \mathrm{C}$. $\mathbf{c}$ Rate capacities and $\mathbf{d}$ cycle performance at $0.5 \mathrm{C}$ of C-Fe $\mathrm{O}_{3}-\mathrm{G}, \mathrm{P}-\mathrm{Fe}_{2} \mathrm{O}_{3}-\mathrm{G}$ and $\mathrm{G}$ cells. e Long-term cycle stability of C-Fe $\mathrm{O}_{3}-\mathrm{G}_{\text {and }} \mathrm{P}-\mathrm{Fe}_{2} \mathrm{O}_{3}-\mathrm{G}$ cells at $2 \mathrm{C}$. f Cycling performance of $\mathrm{C}-\mathrm{Fe}_{2} \mathrm{O}_{3}-\mathrm{G}$ cell with high sulfur loading of $9.41 \mathrm{mg} \mathrm{cm}^{-2}$ at $0.2 \mathrm{C}$ 
battery systems with the sulfur loading of $1.0-1.4 \mathrm{mg} \mathrm{cm}^{-2}$. When increasing the electric current density to $0.2,0.5$, 1.0, 2.0 and $4.0 \mathrm{C}$, the reversible discharge capacities of $\mathrm{C}-\mathrm{Fe}_{2} \mathrm{O}_{3}-\mathrm{G}$ cell could still reach $1115,941,835,760$ and $719 \mathrm{mAh} \mathrm{g}^{-1}$, respectively, which were much higher than the corresponding capacities of $\mathrm{P}-\mathrm{Fe}_{2} \mathrm{O}_{3}-\mathrm{G}$ cell and $\mathrm{G}$ cell. Moreover, the capacity gaps between $\mathrm{C}-\mathrm{Fe}_{2} \mathrm{O}_{3}-\mathrm{G}$ cell and the other two cells with $\mathrm{P}-\mathrm{Fe}_{2} \mathrm{O}_{3}-\mathrm{G}$ or $\mathrm{G}$ gradually expanded with the increase of electric current density, respectively, attaining 172 and $424 \mathrm{mAh} \mathrm{g}^{-1}$ at $4.0 \mathrm{C}$. The corresponding charge-discharge profiles of three batteries at different current densities were recorded, as shown in Fig. S18. Even at a high current densities of $4.0 \mathrm{C}, \mathrm{C}-\mathrm{Fe}_{2} \mathrm{O}_{3}$-G cell still maintained two well-defined discharge plateaus, exhibiting the higher electrochemical stability than two other cell systems. These test results all demonstrated that $\mathrm{C}-\mathrm{Fe}_{2} \mathrm{O}_{3}-\mathrm{G}$ could not only more evidently alleviate the shuttling of LiPSs but also enhance the utilization of sulfur more effectively, which possibly profited from the excellent adsorption capacity and catalytic activity of the high-index crystal facets exposed on $\mathrm{C}-\mathrm{Fe}_{2} \mathrm{O}_{3}$-G.

The enhanced cycling stability of Li-S batteries with $\mathrm{C}-\mathrm{Fe}_{2} \mathrm{O}_{3}$ - $\mathrm{G}$ catalysts was also testified via an endurance test under the galvanostatic mode. The cycle performances at $0.5 \mathrm{C}$ of the batteries with $\mathrm{C}-\mathrm{Fe}_{2} \mathrm{O}_{3}-\mathrm{G}, \mathrm{P}-\mathrm{Fe}_{2} \mathrm{O}_{3}-\mathrm{G}$ and $\mathrm{G}$ are shown in Fig. 4d. It was clear that $\mathrm{C}-\mathrm{Fe}_{2} \mathrm{O}_{3}-\mathrm{G}$ cell delivered higher initial discharge capacities in comparison with $\mathrm{P}-\mathrm{Fe}_{2} \mathrm{O}_{3}-\mathrm{G}$ cell and $\mathrm{G}$ cell, revealing that $\mathrm{C}-\mathrm{Fe}_{2} \mathrm{O}_{3}-\mathrm{G}$ interlayer could reduce the loss of the active sulfur components most effectively [29, 59]. After continuous 300 cycles, $\mathrm{C}-\mathrm{Fe}_{2} \mathrm{O}_{3}$-G cell held a high reversible capacity of $788 \mathrm{mAh}$ $\mathrm{g}^{-1}$ with high average Coulombic efficiency (> 98.5\%), corresponding to the average capacity fading of $0.069 \%$ each cycle. By contrast, $\mathrm{P}-\mathrm{Fe}_{2} \mathrm{O}_{3}$ - $\mathrm{G}$ cell and $\mathrm{G}$ cell, respectively, retained discharge capacities of 616 and $349 \mathrm{mAh} \mathrm{g}^{-1}$ after 300 cycles at $0.5 \mathrm{C}$, respectively, corresponding to two higher capacity decay rates. Consequently, the battery with $\mathrm{C}-\mathrm{Fe}_{2} \mathrm{O}_{3}-\mathrm{G}$ catalyst showed better cycling stability under a low current rate of $0.5 \mathrm{C}$. The long-term cycling stability measurements were also taken under a higher current rate of $2.0 \mathrm{C}$, and the corresponding results are shown in Fig. 4e. C- $\mathrm{Fe}_{2} \mathrm{O}_{3}$-G cell exhibited a higher premier discharge capacity and much better cycling performance than $\mathrm{P}-\mathrm{Fe}_{2} \mathrm{O}_{3}$ $\mathrm{G}$ cell. After 1600 continuous discharging-charging cycle tests, $\mathrm{C}-\mathrm{Fe}_{2} \mathrm{O}_{3}$-G cell still maintained a reversible discharge capacity of $491 \mathrm{mAh} \mathrm{g}^{-1}$, achieving a capacity fading rate as low as $0.025 \%$ every cycle. Besides, the good voltage stability during the long-term charge-discharge cycles further manifested the excellent electrochemical stability of $\mathrm{C}-\mathrm{Fe}_{2} \mathrm{O}_{3}$-G cell (Fig. S19). In comparison, the discharge specific capacity of $\mathrm{P}-\mathrm{Fe}_{2} \mathrm{O}_{3}-\mathrm{G}$ cell decayed to $209 \mathrm{mAh}$ $\mathrm{g}^{-1}$ after 800 continuous cycles, and the capacity fading of each cycle was $0.089 \%$, revealing the worse long-term cycling stability than $\mathrm{C}-\mathrm{Fe}_{2} \mathrm{O}_{3}-\mathrm{G}$ cell at $2.0 \mathrm{C}$. In addition, the Coulombic efficiency of $\mathrm{C}-\mathrm{Fe}_{2} \mathrm{O}_{3}$-G cells had smaller decline compared with $\mathrm{P}-\mathrm{Fe}_{2} \mathrm{O}_{3}-\mathrm{G}$ cells both at 0.5 and 2.0 $\mathrm{C}$, implying better inhibition of $\mathrm{C}-\mathrm{Fe}_{2} \mathrm{O}_{3}-\mathrm{G}$ for LiPS shuttling. The effective suppression of LiPS shuttling would guarantee the slightest corrosions of Li anode, which was identified by the characterization of Li metal anodes in Fig. $\mathrm{S} 20$. The long-term cycling stability of $\mathrm{C}-\mathrm{Fe}_{2} \mathrm{O}_{3}-\mathrm{G}$ cell at a higher current density of $4.0 \mathrm{C}$ was also recorded under the galvanostatic mode. As shown in Fig. S21, C-Fe $\mathrm{O}_{3}-\mathrm{G}$ cell exhibited the good long-term cycling stability at $4.0 \mathrm{C}$, which further confirmed the superiority of $\mathrm{C}-\mathrm{Fe}_{2} \mathrm{O}_{3}-\mathrm{G}$ in improving the performance of $\mathrm{Li}-\mathrm{S}$ batteries.

The chemical stability of $\mathrm{C}-\mathrm{Fe}_{2} \mathrm{O}_{3}-\mathrm{G}$ during the charge-discharge cycle was certified by XRD and XPS analyses. As shown in Fig. S22, all the XRD diffraction peaks of the cycled $\mathrm{C}-\mathrm{Fe}_{2} \mathrm{O}_{3}$-G highly matched with the new $\mathrm{C}-\mathrm{Fe}_{2} \mathrm{O}_{3}$-G. Moreover, the characteristic peak of $\mathrm{Fe}-\mathrm{S}$ bond did not appear in the high-resolution $\mathrm{Fe} 2 \mathrm{p}$ spectrums of the cycled $\mathrm{C}-\mathrm{Fe}_{2} \mathrm{O}_{3}-\mathrm{G}$ (Fig. S23). All these characterization results indicated that the sulfidation reaction of $\mathrm{C}-\mathrm{Fe}_{2} \mathrm{O}_{3}-\mathrm{G}$ by sulfur species did not occur during cycling, which proved the excellent chemical stability of C- $\mathrm{Fe}_{2} \mathrm{O}_{3}$ $\mathrm{G}$ in lithium-sulfur batteries. Taking into account the high requirement of energy density in practical applications, the cycle performances of $\mathrm{C}-\mathrm{Fe}_{2} \mathrm{O}_{3}-\mathrm{G}$ cell with a high sulfur loading of $9.41 \mathrm{mg} \mathrm{cm}^{-2}$ was investigated under the galvanostatic mode. The battery with $\mathrm{C}-\mathrm{Fe}_{2} \mathrm{O}_{3}-\mathrm{G}$ electrocatalysts, respectively, delivered discharge capacity of 1192 and 1087 $\mathrm{mAh} \mathrm{g}^{-1}$ at 0.1 and $0.2 \mathrm{C}$ (Fig. S24). After 85 continuous discharging-charging cycles at $0.2 \mathrm{C}$, the cell maintained a reversible discharge capacity of $809 \mathrm{mAh} \mathrm{g}^{-1}$, corresponding to a favorable areal capacity of $7.61 \mathrm{mAh} \mathrm{cm}^{-2}$, which was much superior to the commercial LIBs. This high discharge capacity and superior rate performance as well as outstanding cycle span are prominent in comparison with previous works (Table S1). All the research results confirmed that $\mathrm{C}-\mathrm{Fe}_{2} \mathrm{O}_{3}-\mathrm{G}$ with high-index crystal faces could effectively elevate the electrochemical performance of sulfur species 
in a working battery, which was conducive to the practical application of $\mathrm{Li}-\mathrm{S}$ batteries.

\subsection{DFT Analysis}

The DFT calculations were carried out to further uncover the mechanism of $\mathrm{C}-\mathrm{Fe}_{2} \mathrm{O}_{3}$-G electrocatalysts more efficiently inhibiting the shuttling of LiPSs and accelerating the redox kinetics of sulfur species. The projected density of states (PDOS) of Fe-3d orbitals for different crystal facets before and after interacting with $\mathrm{Li}_{2} \mathrm{~S}_{4}$ is shown in Fig. 5a, revealing the electronic configuration of $\mathrm{Fe}$ center, which was related to surface adsorbability and catalytic activity of Fe-based catalysts [59]. In Fig. 5b, the d-band centers of $\mathrm{Fe}$ atoms on the $(13 \overline{4} 4)(-2.26 \mathrm{eV})$ and $(12 \overline{3} 8)(-2.33 \mathrm{eV})$ facets of $\mathrm{C}-\mathrm{Fe}_{2} \mathrm{O}_{3}$ were closer toward the Fermi level than those on $\mathrm{Fe}_{2} \mathrm{O}_{3}(01 \overline{1} 2)$ facet $(-2.47 \mathrm{eV})$, indicating the stronger adsorption capacity and better electronic conductivity on $\mathrm{Fe}_{2} \mathrm{O}_{3}(13 \overline{4} 4)$ and $(12 \overline{3} 8)$ facets, which would be beneficial to the adsorption and further conversion of LiPSs [9, 59, 62]. After interacting with LiPSs, the d-band center of $\mathrm{Fe}$ atoms on $\mathrm{Fe}_{2} \mathrm{O}_{3}(13 \overline{4} 4)$ facet shifted more obviously to the Fermi level compared to those on the other two crystal (a)
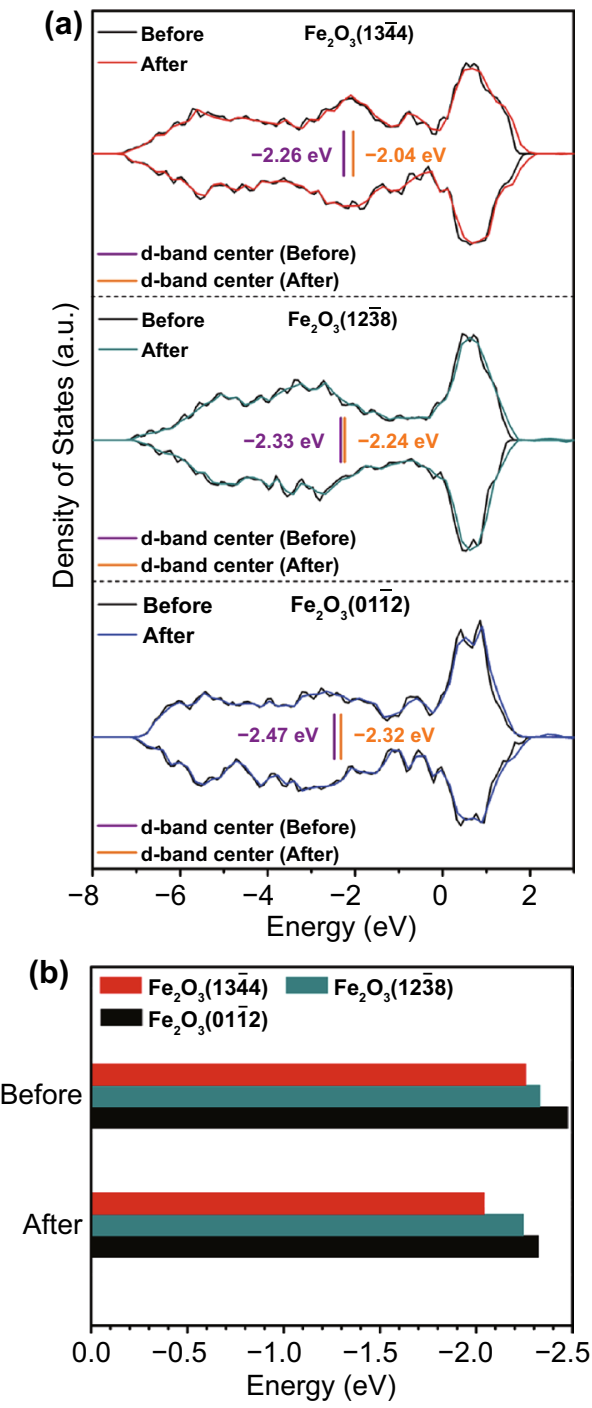

(c)
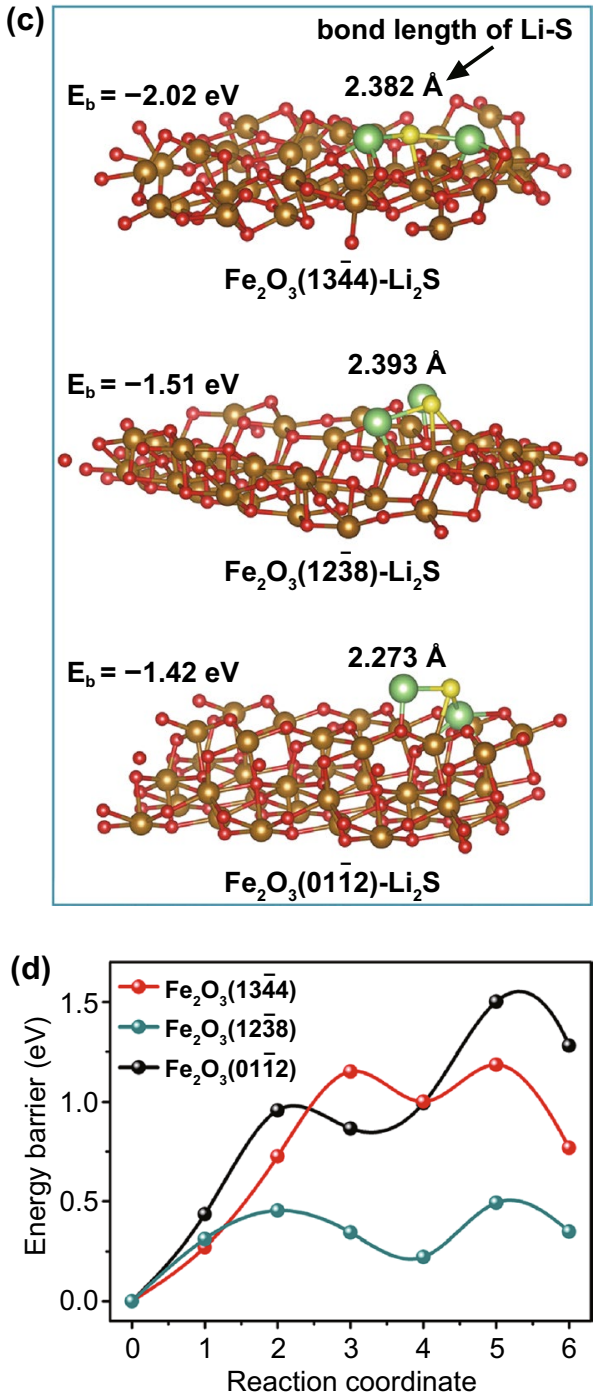

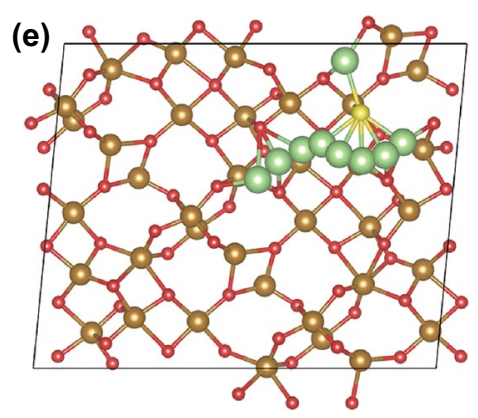

(f)

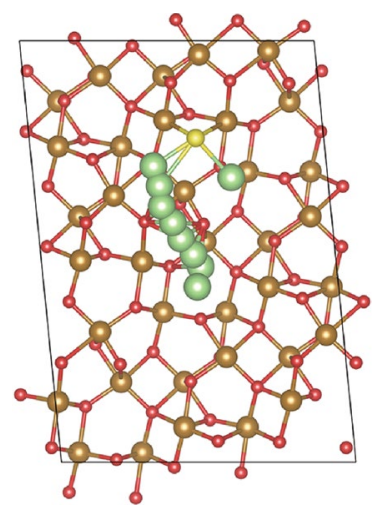

(g)

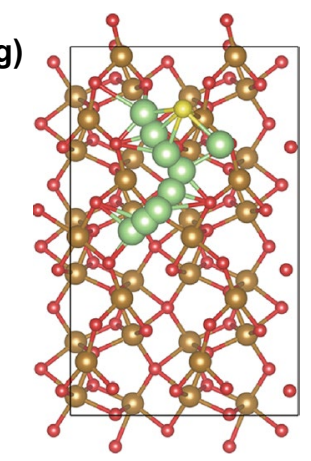

Fig. 5 a Projected density of states and $\mathbf{b}$ d-band center of the $\mathrm{Fe}$ atoms exposed on different $\mathrm{Fe}_{2} \mathrm{O}_{3}$ crystal planes before and after interacting with $\mathrm{Li}_{2} \mathrm{~S}_{4}$. c Optimized geometries and $\mathbf{d}$ decomposition energy barriers of $\mathrm{Li}_{2} \mathrm{~S}$ adsorbed on different $\mathrm{Fe}_{2} \mathrm{O}_{3}$ crystal faces. e- $\mathbf{g} \mathrm{Li}_{2} \mathrm{~S}$ decomposition path on $\mathrm{Fe}_{2} \mathrm{O}_{3}(13 \overline{4} 4),(12 \overline{3} 8)$ and $(01 \overline{1} 2)$ facets. The $\mathrm{Li}, \mathrm{S}, \mathrm{Fe}$ and $\mathrm{O}$ atoms are severally indicated by green, yellow, gold and red balls 
facets, corresponding to the strongest interaction between catalyst surface and adsorbates [63]. $\mathrm{Li}_{2} \mathrm{~S}_{4}$ adsorbed on $\mathrm{Fe}_{2} \mathrm{O}_{3}(13 \overline{4} 4)$ facet displayed an unusual distorted geometry with broken $\mathrm{Li}-\mathrm{S}$ and $\mathrm{S}-\mathrm{S}$ bond (Fig. 2a), reflecting that $\mathrm{Fe}_{2} \mathrm{O}_{3}(13 \overline{4} 4)$ facets could adsorb and activate $\mathrm{Li}_{2} \mathrm{~S}_{4}$ more effectively and expedite the decomposition of $\mathrm{Li}_{2} \mathrm{~S}_{4}$ [29]. In addition, the adsorption of $\mathrm{Li}_{2} \mathrm{~S}$ on different $\mathrm{Fe}_{2} \mathrm{O}_{3}$ crystal faces was analyzed by DFT calculations (Figs. $5 \mathrm{c}$ and $\mathrm{S} 25$ ). The calculated binding energies of $\mathrm{Li}_{2} \mathrm{~S}$ on $\mathrm{Fe}_{2} \mathrm{O}_{3}(13 \overline{4} 4)$ and $(12 \overline{3} 8)$ facets were -2.02 and $-1.51 \mathrm{eV}$, respectively, which were more negative in comparison with that on $\mathrm{Fe}_{2} \mathrm{O}_{3}(01 \overline{1} 2)$ facet $(-1.42 \mathrm{eV})$, availing more uniform $\mathrm{Li}_{2} \mathrm{~S}$ nucleation and deposition [59]. It is worth noting that the bond lengths of $\mathrm{Li}-\mathrm{S}$ in adsorbed $\mathrm{Li}_{2} \mathrm{~S}$ both on $\mathrm{Fe}_{2} \mathrm{O}_{3}(13 \overline{4} 4)$ (2.382 $\AA$ ) and $(12 \overline{3} 8)(2.393 \AA)$ facets were significantly longer than that on $\mathrm{Fe}_{2} \mathrm{O}_{3}(01 \overline{1} 2)$ facet $(2.273 \AA$ ), which suggested that $\mathrm{C}-\mathrm{Fe}_{2} \mathrm{O}_{3}$ as catalysts could more efficiently weaken the binding between $\mathrm{Li}$ and $\mathrm{S}$ of $\mathrm{Li}_{2} \mathrm{~S}$ and then reduce the decomposition energy barrier of $\mathrm{Li}_{2} \mathrm{~S}$ [64]. Afterward, the superiority of $\mathrm{C}-\mathrm{Fe}_{2} \mathrm{O}_{3}$ was further confirmed by the theoretical analysis of decomposition energy barrier of $\mathrm{Li}_{2} \mathrm{~S}$ on different $\mathrm{Fe}_{2} \mathrm{O}_{3}$ crystal faces. The energy profiles of $\mathrm{Li}_{2} \mathrm{~S}$ decomposition and corresponding decomposition path are shown in Fig. 5d-g. The decomposition energy barriers of $\mathrm{Li}_{2} \mathrm{~S}$ on $\mathrm{Fe}_{2} \mathrm{O}_{3}(12 \overline{3} 8)$ $(0.49 \mathrm{eV})$ and $(13 \overline{4} 4)(1.18 \mathrm{eV})$ facets were significantly lower than that on $\mathrm{Fe}_{2} \mathrm{O}_{3}(01 \overline{1} 2)$ facet $(1.51 \mathrm{eV})$, which revealed that $\mathrm{C}-\mathrm{Fe}_{2} \mathrm{O}_{3}$ possessed stronger catalytic capacity to break $\mathrm{Li}-\mathrm{S}$ bonds more easily and enhance the oxidative decomposition kinetics of $\mathrm{Li}_{2} \mathrm{~S}$ [65]. These theoretical calculation results all demonstrated that the higher sulfur utilization and faster reversible conversion of sulfur species could realize with the help of $\mathrm{C}-\mathrm{Fe}_{2} \mathrm{O}_{3}$ - $\mathrm{G}$ catalysts compared with $\mathrm{P}-\mathrm{Fe}_{2} \mathrm{O}_{3}-\mathrm{G}$, which was in good agreement with electrochemical measurement results.

\section{Conclusions}

We successfully constructed $\mathrm{Fe}_{2} \mathrm{O}_{3}$ concave nanocubes with high-index facets anchored on reduced graphene oxide through a simple hydrothermal strategy and applied it as the electrocatalysts to investigate the structure-activity relationship between the surface structures of crystal materials and its chemisorption/catalytic conversion for sulfur species. Experiment researches and DFT results all revealed that the strong adsorption capacity and high catalytic activity of $\mathrm{C}-\mathrm{Fe}_{2} \mathrm{O}_{3}$-G stemmed from the active high-index $\mathrm{Fe}_{2} \mathrm{O}_{3}$ crystal faces with abundant unsaturated $\mathrm{Fe}$ sites. These high-activity crystal facets could not only enhance chemisorption of LiPSs but also accelerate the liquid-solid conversion of LiPSs and the oxidative decomposition of $\mathrm{Li}_{2} \mathrm{~S}$, which significantly improve the utilization of sulfur. Therefore, the batteries with $\mathrm{C}-\mathrm{Fe}_{2} \mathrm{O}_{3}-\mathrm{G}$ catalysts delivered an outstanding premier discharge capacity of $1521 \mathrm{mAh} \mathrm{g}^{-1}$ at $0.1 \mathrm{C}$, as well as the stable cycling performance during 1600 cycles at $2 \mathrm{C}$ with a low capacity decaying of $0.025 \%$ every cycle. Moreover, the battery with a high sulfur loading of $9.41 \mathrm{mg} \mathrm{cm}^{-2}$ cycled steadily at $0.2 \mathrm{C}$ and a high areal capacity of $7.61 \mathrm{mAh} \mathrm{cm}^{-2}$ was maintained after 85 cycles. This work exhibited pioneering insights into the crystal facet effect in Li-S electrochemistry and provided instructive guidance for fabricating novel catalysts applied in advanced $\mathrm{Li}-\mathrm{S}$ batteries by tuning the surface structure of materials.

Acknowledgements This work was supported by the National Natural Science Foundation of China (No. 22078078), the Natural Science Foundation of Heilongjiang Province (No. LH2020B008) and the State Key Laboratory of Urban Water Resource and Environment, Harbin Institute of Technology (No. 2019DX13).

Funding Open access funding provided by Shanghai Jiao Tong University.

Open Access This article is licensed under a Creative Commons Attribution 4.0 International License, which permits use, sharing, adaptation, distribution and reproduction in any medium or format, as long as you give appropriate credit to the original author(s) and the source, provide a link to the Creative Commons licence, and indicate if changes were made. The images or other third party material in this article are included in the article's Creative Commons licence, unless indicated otherwise in a credit line to the material. If material is not included in the article's Creative Commons licence and your intended use is not permitted by statutory regulation or exceeds the permitted use, you will need to obtain permission directly from the copyright holder. To view a copy of this licence, visit http://creativecommons.org/licenses/by/4.0/.

Supplementary Information The online version contains supplementary material available at https://doi.org/10.1007/ s40820-021-00769-2. 


\section{References}

1. P.G. Bruce, S.A. Freunberger, L.J. Hardwick, J.M. Tarascon, Li- $\mathrm{O}_{2}$ and Li-S batteries with high energy storage. Nat. Mater. 11, 19-29 (2012). https://doi.org/10.1038/nmat3191

2. Z.P. Cano, D. Banham, S. Ye, A. Hintennach, J. Lu et al., Batteries and fuel cells for emerging electric vehicle markets. Nat. Energy 3, 279-289 (2018). https://doi.org/10.1038/ s41560-018-0108-1

3. Z.W. Seh, W. Li, J.J. Cha, G. Zheng, Y. Yang et al., Sulphur$\mathrm{TiO}_{2}$ yolk-shell nanoarchitecture with internal void space for long-cycle lithium-sulphur batteries. Nat. Commun. 4, 1331 (2013). https://doi.org/10.1038/ncomms2327

4. R.F. Service, Lithium-sulfur batteries poised for leap. Science 359(6380), 1080-1081 (2018). http://science.sciencemag.org/ content/359/6380/1080

5. C. Zhao, G.L. Xu, Z. Yu, L. Zhang, I. Hwang et al., A highenergy and long-cycling lithium-sulfur pouch cell via a macroporous catalytic cathode with double-end binding sites. Nat. Nanotechnol. 16, 166-173 (2021). https://doi.org/10. 1038/s41565-020-00797-w

6. B. Guan, X. Sun, Y. Zhang, X. Wu, Y. Qiu et al., The discovery of interfacial electronic interaction within cobalt boride@ MXene for high performance lithium-sulfur batteries. Chin. Chem. Lett. 32, 2249-2253 (2021). https://doi.org/10.1016/j. cclet.2020.12.051

7. Z.W. Seh, Y. Sun, Q. Zhang, Y. Cui, Designing high-energy lithium-sulfur batteries. Chem. Soc. Rev. 45(20), 5605-5634 (2016). https://doi.org/10.1039/C5CS00410A

8. Y.X. Yao, X.Q. Zhang, B.Q. Li, C. Yan, P.Y. Chen et al., A compact inorganic layer for robust anode protection in lithiumsulfur batteries. InfoMat 2(2), 379-388 (2020). https://doi.org/ 10.1002/inf2.12046

9. X. Wang, D. Luo, J. Wang, Z. Sun, G. Cui et al., Strain engineering of a MXene/CNT hierarchical porous hollow microsphere electrocatalyst for a high-efficiency lithium polysulfide conversion process. Angew. Chem. Int. Ed. 60(5), 2371-2378 (2021). https://doi.org/10.1002/anie.202011493

10. L. Peng, Z. Wei, C. Wan, J. Li, Z. Chen et al., A fundamental look at electrocatalytic sulfur reduction reaction. Nat. Catal. 3, 762-770 (2020). https://doi.org/10.1038/s41929-020-0498-x

11. J.R. He, G. Hartmann, M. Lee, G.S. Hwang, Y.F. Chen et al., Freestanding $1 \mathrm{~T} \mathrm{MoS}_{2}$ /graphene heterostructures as a highly efficient electrocatalyst for lithium polysulfides in Li-S batteries. Energy Environ. Sci. 12(1), 344-350 (2019). https://doi. org/10.1039/C8EE03252A

12. L. Zhou, D.L. Danilov, R.A. Eichel, P.H.L. Notten, Host materials anchoring polysulfides in $\mathrm{Li}-\mathrm{S}$ batteries reviewed. Adv. Energy Mater. 11(15), 2001304 (2021). https://doi.org/10. 1002/aenm.202001304

13. X. Liang, C. Hart, Q. Pang, A. Garsuch, T. Weiss et al., A highly efficient polysulphide mediator for lithium-sulphur batteries. Nat. Commun. 6, 5682 (2015). https://doi.org/10.1038/ ncomms6682

14. Z. Shi, M. Li, J. Sun, Z. Chen, Defect engineering for expediting Li-S chemistry: strategies, mechanisms, and perspectives. Adv. Energy Mater. 11(23), 2100332 (2021). https://doi.org/10.1002/aenm.202100332

15. G. Zhang, H.J. Peng, C.Z. Zhao, X. Chen, L.D. Zhao et al., The radical pathway based on a lithium-metal-compatible high-dielectric electrolyte for lithium-sulfur batteries. Angew. Chem. Int. Ed. 57(51), 16732-16736 (2018). https:// doi.org/10.1002/anie.201810132

16. X. Song, D. Tian, Y. Qiu, X. Sun, B. Jiang et al., Improving poisoning resistance of electrocatalysts via alloying strategy for high-performance lithium-sulfur batteries. Energy Storage Mater. 41, 248-254 (2021). https://doi.org/10.1016/j. ensm.2021.05.028

17. W. Xue, Z. Shi, L. Suo, C. Wang, Z. Wang et al., Intercalation-conversion hybrid cathodes enabling Li-S full-cell architectures with jointly superior gravimetric and volumetric energy densities. Nat. Energy 4, 374-382 (2019). https:// doi.org/10.1038/s41560-019-0351-0

18. J. Zhou, X. Liu, L. Zhu, J. Zhou, Y. Guan et al., Deciphering the modulation essence of $\mathrm{p}$ bands in Co-based compounds on Li-S chemistry. Joule 2(12), 2681-2693 (2018). https:// doi.org/10.1016/j.joule.2018.08.010

19. Z. Li, J. Zhang, B. Guan, D. Wang, L.M. Liu et al., A sulfur host based on titanium monoxide@ carbon hollow spheres for advanced lithium-sulfur batteries. Nat. Commun. 7, 13065 (2016). https://doi.org/10.1038/ncomms 13065

20. Z. Yuan, H.J. Peng, T.Z. Hou, J.Q. Huang, C.M. Chen et al., Powering lithium-sulfur battery performance by propelling polysulfide redox at sulfiphilic hosts. Nano Lett. 16(1), 519527 (2016). https://doi.org/10.1021/acs.nanolett.5b04166

21. D. Tian, X. Song, Y. Qiu, X. Sun, B. Jiang et al., Basalplane-activated molybdenum sulfide nanosheets with suitable orbital orientation as efficient electrocatalysts for lithium-sulfur batteries. ACS Nano 15(10), 16515-16524 (2021). https://doi.org/10.1021/acsnano.1c06067

22. J. Park, B.C. Yu, J.S. Park, J.W. Choi, C. Kim et al., Tungsten disulfide catalysts supported on a carbon cloth interlayer for high performance Li-S battery. Adv. Energy Mater. 7, 1602567 (2017). https://doi.org/10.1002/aenm.201602567

23. Y. Yan, P. Zhang, Z. Qu, M. Tong, S. Zhao et al., Carbon/ sulfur aerogel with adequate mesoporous channels as robust polysulfide confinement matrix for highly stable lithiumsulfur battery. Nano Lett. 20(10), 7662-7669 (2020). https:// doi.org/10.1021/acs.nanolett.0c03203

24. N. Wei, L. Yu, Z. Sun, Y. Song, M. Wang et al., Scalable salt-templated synthesis of nitrogen-doped graphene nanosheets toward printable energy storage. ACS Nano 13(7), 7517-7526 (2019). https://doi.org/10.1021/acsnano. $9 \mathrm{~b} 03157$

25. Z. Wei, Y. Ren, J. Sokolowski, X. Zhu, G. Wu, Mechanistic understanding of the role separators playing in advanced lithium-sulfur batteries. InfoMat 2(3), 483-508 (2020). https:// doi.org/10.1002/inf2.12097

26. Q. Pang, D. Kundu, M. Cuisinier, L.F. Nazar, Surfaceenhanced redox chemistry of polysulphides on a metallic and polar host for lithium-sulphur batteries. Nat. Commun. 5, 4759 (2014). https://doi.org/10.1038/ncomms5759 
27. X. Tao, J. Wang, C. Liu, H. Wang, H. Yao et al., Balancing surface adsorption and diffusion of lithium-polysulfides on nonconductive oxides for lithium-sulfur battery design. Nat. Commun. 7, 11203 (2016). https://doi.org/10.1038/ncomm s11203

28. C. Ye, Y. Jiao, H. Jin, A.D. Slattery, K. Davey et al., 2D MoNVN heterostructure to regulate polysulfides for highly efficient lithium-sulfur batteries. Angew. Chem. Int. Ed. 57(51), 16703-16707 (2018). https://doi.org/10.1002/anie.201810579

29. D. Tian, X. Song, M. Wang, X. Wu, Y. Qiu et al., MoN supported on graphene as a bifunctional interlayer for advanced Li-S batteries. Adv. Energy Mater. 9(46), 1901940 (2019). https://doi.org/10.1002/aenm.201901940

30. X. Liu, J.Q. Huang, Q. Zhang, L. Mai, Nanostructured metal oxides and sulfides for lithium-sulfur batteries. Adv. Mater. 29(20), 1601759 (2017). https://doi.org/10.1002/adma.20160 1759

31. J. Xu, L. Yang, S. Cao, J. Wang, Y. Ma et al., Sandwiched cathodes assembled from $\mathrm{CoS}_{2}$-modified carbon clothes for high-performance lithium-sulfur batteries. Adv. Sci. 8(16), 2101019 (2021). https://doi.org/10.1002/advs.202101019

32. Y. You, Y. Ye, M. Wei, W. Sun, Q. Tang et al., Three-dimensional $\mathrm{MoS}_{2} / \mathrm{rGO}$ foams as efficient sulfur hosts for high-performance lithium-sulfur batteries. Chem. Eng. J. 355, 671-678 (2019). https://doi.org/10.1016/j.cej.2018.08.176

33. H. Yuan, H.J. Peng, B.Q. Li, J. Xie, L. Kong et al., Conductive and catalytic triple-phase interfaces enabling uniform nucleation in high-rate lithium-sulfur batteries. Adv. Energy Mater. 9(1), 1802768 (2019). https://doi.org/10.1002/aenm.20180 2768

34. Y. Zhong, L. Yin, P. He, W. Liu, Z. Wu et al., Surface chemistry in cobalt phosphide-stabilized lithium-sulfur batteries. J. Am. Chem. Soc. 140(4), 1455-1459 (2018). https://doi.org/ $10.1021 /$ jacs.7b11434

35. L. Wang, N.T. Nguyen, Z.Q. Shen, P. Schmuki, Y.P. Bi, Hematite dodecahedron crystals with high-index facets grown and grafted on one dimensional structures for efficient photoelectrochemical $\mathrm{H}_{2}$ generation. Nano Energy 50, 331-338 (2018). https://doi.org/10.1016/j.nanoen.2018.05.039

36. J.Z. Yin, Z.N. Yu, F. Gao, J.J. Wang, H.A. Pang et al., Lowsymmetry iron oxide nanocrystals bound by high-index facets. Angew. Chem. Int. Ed. 49(36), 6328-6332 (2010). https://doi. org/10.1002/anie.201002557

37. X. Han, G. He, Y. He, J. Zhang, X. Zheng et al., Engineering catalytic active sites on cobalt oxide surface for enhanced oxygen electrocatalysis. Adv. Energy Mater. 8(10), 1702222 (2018). https://doi.org/10.1002/aenm.201702222

38. J. Ouyang, J. Pei, Q. Kuang, Z. Xie, L. Zheng, Supersaturation-controlled shape evolution of $\alpha \mathrm{Fe}_{2} \mathrm{O}_{3}$ nanocrystals and their facet-dependent catalytic and sensing properties. ACS Appl. Mater. Interfaces 6(15), 12505-12514 (2014). https:// doi.org/10.1021/am502358g

39. N. Tian, Z.Y. Zhou, S.G. Sun, Y. Ding, Z.L. Wang, Synthesis of tetrahexahedral platinum nanocrystals with high-index facets and high electro-oxidation activity. Science 316(5825), 732-735 (2007). https://doi.org/10.1126/science.1140484
40. C. Xiao, B.A. Lu, P. Xue, N. Tian, Z.Y. Zhou et al., Highindex-facet- and high-surface-energy nanocrystals of metals and metal oxides as highly efficient catalysts. Joule 4(12), 2562-2598 (2020). https://doi.org/10.1016/j.joule.2020.10. 002

41. B. Jiang, L. Xu, W. Chen, C. Zou, Y. Yang et al., $\mathrm{Ag}^{+}$-assisted heterogeneous growth of concave Pd@Au nanocubes for surface enhanced Raman scattering (SERS). Nano Res. 10, 3509-3521 (2017). https://doi.org/10.1007/ s12274-017-1562-y

42. X. Han, M. Jin, S. Xie, Q. Kuang, Z. Jiang et al., Synthesis of tin dioxide octahedral nanoparticles with exposed high-energy 221 facets and enhanced gas-sensing properties. Angew. Chem. Int. Ed. 48(48), 9180-9183 (2009). https://doi.org/10. 1002/anie. 200903926

43. S. Sun, X. Zhang, J. Cui, Q. Yang, S. Liang, High-index faceted metal oxide micro-/nanostructures: a review on their characterization, synthesis and applications. Nanoscale 11(34), 15739-15762 (2019). https://doi.org/10.1039/C9NR05107D

44. W. Guo, W. Sun, L.P. Lv, S. Kong, Y. Wang, Microwaveassisted morphology evolution of Fe-based metal-organic frameworks and their derived $\mathrm{Fe}_{2} \mathrm{O}_{3}$ nanostructures for $\mathrm{Li}$-ion storage. ACS Nano 11, 4198-4205 (2017). https://doi.org/10. 1021/acsnano.7b01152

45. X. Zhu, Y. Zhu, S. Murali, M.D. Stoller, R.S. Ruoff, Nanostructured reduced graphene oxide/ $\mathrm{Fe}_{2} \mathrm{O}_{3}$ composite as a highperformance anode material for lithium ion batteries. ACS Nano 5, 3333-3338 (2011). https://doi.org/10.1021/nn200493r

46. W. Wu, R. Hao, F. Liu, X. Su, Y. Hou, Single-crystalline $\alpha-\mathrm{Fe}_{2} \mathrm{O}_{3}$ nanostructures: controlled synthesis and high-index plane-enhanced photodegradation by visible light. J. Mater. Chem. A 1(23), 6888-6894 (2013). https://doi.org/10.1039/ C3TA10886D

47. C.J. Jia, L.D. Sun, F. Luo, X.D. Han, L.J. Heyderman et al., Large-scale synthesis of single-crystalline iron oxide magnetic nanorings. J. Am. Chem. Soc. 130, 16968-16977 (2008). https://doi.org/10.1021/ja805152t

48. L. Sun, X. Han, K. Liu, S. Yin, Q. Chen et al., Template-free construction of hollow $\alpha-\mathrm{Fe}_{2} \mathrm{O}_{3}$ hexagonal nanocolumn particles with an exposed special surface for advanced gas sensing properties. Nanoscale 7(21), 9416-9420 (2015). https://doi. org/10.1039/C5NR01790D

49. H. Wu, T. Yang, Y. Du, L. Shen, G.W. Ho, Identification of facet-governing reactivity in hematite for oxygen evolution. Adv. Mater. 30(52), 1804341 (2018). https://doi.org/10.1002/ adma.201804341

50. H. Liang, X. Jiang, Z. Qi, W. Chen, Z. Wu et al., Hematite concave nanocubes and their superior catalytic activity for low temperature CO oxidation. Nanoscale 6(13), 7199-7203 (2014). https://doi.org/10.1039/C4NR00552J

51. F. Gao, R. Liu, J. Yin, Q. Lu, Synthesis of polyhedral iron oxide nanocrystals bound by high-index facets. Sci. China Chem. 57, 114-121 (2014). https://doi.org/10.1007/ s11426-013-4973-y

52. C. Zheng, S. Niu, W. Lv, G. Zhou, J. Li et al., Propelling polysulfides transformation for high-rate and long-life 
lithium-sulfur batteries. Nano Energy 33, 306-312 (2017). https://doi.org/10.1016/j.nanoen.2017.01.040

53. D.P. Cai, T. Yang, B. Liu, D.D. Wang, Y. Liu et al., A nanocomposite of tin dioxide octahedral nanocrystals exposed to high-energy facets anchored onto graphene sheets for high performance lithium-ion batteries. J. Mater. Chem. A 2(34), 13990-13995 (2014). https://doi.org/10.1039/C4TA01850H

54. L.L. Feng, G. Yu, Y. Wu, G.D. Li, H. Li et al., High-index faceted $\mathrm{Ni}_{3} \mathrm{~S}_{2}$ nanosheet arrays as highly active and ultrastable electrocatalysts for water splitting. J. Am. Chem. Soc. 137(44), 14023-14026 (2015). https://doi.org/10.1021/jacs.5b08186

55. B. Jiang, Y. Yuan, W. Wang, K. He, C. Zou et al., Surface lattice engineering for fine-tuned spatial configuration of nanocrystals. Nat. Commun. 12, 5661 (2021). https://doi.org/ 10.1038/s41467-021-25969-7

56. Y. Niu, Y. Yuan, Q. Zhang, F. Chang, L. Yang et al., Morphology-controlled synthesis of metal-organic frameworks derived lattice plane-altered iron oxide for efficient trifunctional electrocatalysts. Nano Energy 82, 105699 (2021). https://doi.org/ 10.1016/j.nanoen.2020.105699

57. B. Wei, C. Shang, X. Wang, G. Zhou, Conductive FeOOH as multifunctional interlayer for superior lithium-sulfur batteries. Small 16, 2002789 (2020). https://doi.org/10.1002/smll.20200 2789

58. M. Chen, H. Yin, X. Li, Y. Qiu, G. Cao et al., Facet- and defect-engineered $\mathrm{Pt} / \mathrm{Fe}_{2} \mathrm{O}_{3}$ nanocomposite catalyst for catalytic oxidation of airborne formaldehyde under ambient conditions. J. Hazard. Mater. 395, 122628 (2020). https://doi.org/ 10.1016/j.jhazmat.2020.122628

59. Y. Qiu, L. Fan, M. Wang, X. Yin, X. Wu et al., Precise synthesis of $\mathrm{Fe}-\mathrm{N}_{2}$ sites with high activity and stability for long-life lithium-sulfur batteries. ACS Nano 14(1), 16105-16113 (2020). https://doi.org/10.1021/acsnano.0c08056

60. J. Shen, X. Xu, J. Liu, Z. Liu, F. Li et al., Mechanistic understanding of metal phosphide host for sulfur cathode in highenergy-density lithium-sulfur batteries. ACS Nano 13(8), 8986-8996 (2019). https://doi.org/10.1021/acsnano.9b02903

61. Z.Q. Ye, Y. Jiang, L. Li, F. Wu, R.J. Chen, A high-efficiency CoSe electrocatalyst with hierarchical porous polyhedron nanoarchitecture for accelerating polysulfides conversion in Li-S batteries. Adv. Mater. 32(32), 2002168 (2020). https:// doi.org/10.1002/adma.202002168

62. H.B. Tao, L. Fang, J. Chen, H.B. Yang, J. Gao et al., Identification of surface reactivity descriptor for transition metal oxides in oxygen evolution reaction. J. Am. Chem. Soc. 138, 9978-9985 (2016). https://doi.org/10.1021/jacs.6b05398

63. J. Yu, J. Xiao, A. Li, Z. Yang, L. Zeng et al., Enhanced multiple anchoring and catalytic conversion of polysulfides by amorphous $\mathrm{MoS}_{3}$ nanoboxes for high-performance Li-S batteries. Angew. Chem. Int. Ed. 59(31), 13071-13078 (2020). https://doi.org/10.1002/anie.202004914

64. M. Wang, L. Fan, X. Sun, B. Guan, B. Jiang et al., Nitrogen doped $\mathrm{CoSe}_{2}$ as a bifunctional catalyst for high areal capacity and lean electrolyte of Li-S battery. ACS Energy Lett. 5(9), 3041-3050 (2020). https://doi.org/10.1021/acsenergylett. $0 \mathrm{c} 01564$

65. Z.Z. Du, X.J. Chen, W. Hu, C.H. Chuang, S. Xie et al., Cobalt in nitrogen-doped graphene as single-atom catalyst for highsulfur content lithium-sulfur batteries. J. Am. Chem. Soc. 141(9), 3977-3985 (2019). https://doi.org/10.1021/jacs.8b129 73 